\title{
Direct monitoring of active geohazards: emerging geophysical tools for deep-water assessments
}

\author{
Michael A. Clare ${ }^{1 *}$, Mark E. Vardy ${ }^{1}$, Matthieu J.B. Cartigny ${ }^{2}$, \\ Peter J. Talling 2 , Matthew D. Himsworth ${ }^{3}$, Justin K. Dix ${ }^{4}$, John M. Harris ${ }^{5}$, \\ Richard J.S. Whitehouse ${ }^{5}$ and Mohammad Belal ${ }^{3}$ \\ ${ }^{1}$ National Oceanography Centre, University of Southampton Waterfront Campus, European Way, Southampton, SO14 $3 Z$ H, \\ United Kingdom \\ ${ }^{2}$ Departments of Earth Science and Geography, University of Durham, Durham, DH1 3LE, United Kingdom \\ ${ }^{3}$ School of Physics and Astronomy, University of Southampton, Highfield, Southampton, SO17 1BJ, United Kingdom \\ ${ }^{4}$ National Oceanography Centre, School of Ocean and Earth Science, University of Southampton, Southampton SO14 $3 Z$ Z, \\ United Kingdom \\ ${ }^{5}$ HR Wallingford, Howbery Park, Wallingford, Oxfordshire, OX10 8BA, United Kingdom
}

Received November 2016, revision accepted June 2017

\begin{abstract}
Seafloor networks of cables, pipelines, and other infrastructure underpin our daily lives, providing communication links, information, and energy supplies. Despite their global importance, these networks are vulnerable to damage by a number of natural seafloor hazards, including landslides, turbidity currents, fluid flow, and scour. Conventional geophysical techniques, such as high-resolution reflection seismic and side-scan sonar, are commonly employed in geohazard assessments. These conventional tools provide essential information for route planning and design; however, such surveys provide only indirect evidence of past processes and do not observe or measure the geohazard itself. As such, many numerical-based impact models lack field-scale calibration, and much uncertainty exists about the triggers, nature, and frequency of deep-water geohazards. Recent advances in technology now enable a step change in their understanding through direct monitoring. We outline some emerging monitoring tools and how they can quantify key parameters for deepwater geohazard assessment. Repeat seafloor surveys in dynamic areas show that solely relying on evidence from past deposits can lead to an under-representation of the geohazard events. Acoustic Doppler current profiling provides new insights into the structure of turbidity currents, whereas instrumented mobile sensors record the nature of movement at the base of those flows for the first time. Existing and bespoke cabled networks enable high bandwidth, low power, and distributed measurements of parameters such as strain across large areas of seafloor. These techniques provide valuable new measurements that will improve geohazard assessments and should be deployed in a complementary manner alongside conventional geophysical tools.
\end{abstract}

\section{INTRODUCTION}

Subsea infrastructure networks underpin our daily lives, providing critical global communication links and supporting our demand for energy supplies. More than $95 \%$ of all digital data traffic (including Internet, financial, and military traffic) is transmitted by a global network of subsea cables (Carter et al. 2014). With trillions of dollars traded per day on this network, breaks at strategically important points have a direct knock-on effect to global financial trading (Carter et al. 2009). Cable repairs can run into

*michael.clare@noc.ac.uk hundreds of millions of dollars, and the time required to remedy the break can lead to temporary isolation of important trading hubs and disruption of global supply chains (Carter et al. 2009; Gavey et al. 2016). Offshore oil and gas production similarly relies on arrays of seafloor infrastructure to transport hydrocarbons (pipelines and flowlines) and provide communications and chemicals for production (umbilicals). These linear structures are potential weak points in subsea field developments (Clare et al. 2015a). Damage to seafloor oil and gas infrastructure can lead to delayed production, or even uncontrolled loss of hydrocarbons to the marine environment, which is difficult to remedy in deep water 
(Kaiser, Yu and Jablonowski 2009; Skogdalen and Vinnem 2012). Therefore, avoidance of hazardous areas is preferred but is not always an option. Exploitation of new hydrocarbon reserves and the global networking of seafloor cables necessitate the crossing of deep-water settings, prone to a range of marine geohazards that can adversely affect seafloor infrastructure (Thomas, Hooper and Clare 2010; Spinewine et al. 2013). Thus, we need to understand and mitigate the risk posed by marine geohazards to strategically important seafloor infrastructure (Campbell 1999).

\section{AIMS}

Existing conventional tools provide valuable insights into many aspects of marine geohazards, yet important knowledge gaps remain. We first aim to identify emerging geophysical tools that enable direct monitoring of marine geohazards. Lessons have been learned from previous studies where equipment has been damaged by the very processes that we wish to observe. Second, we show how these techniques can fill knowledge gaps concerning key parameters for geohazard assessment. Finally, we outline how direct geophysical monitoring techniques can complement conventional surveys to improve confidence in quantified deepwater risk assessment.

\section{MARINE GEOHAZARDS AND CONVENTIONAL ASSESSMENT TECHNIQUES}

A number of processes can constitute a marine geohazard, but here, we specifically focus on (i) submarine landslides, (ii) turbidity currents, (iii) scour and seafloor sediment mobility, and (iv) sub-surface fluid flow and seafloor expulsion. We now outline some of the impacts associated with these geohazards.

Submarine landslides can be prodigious-scale $\left(>>1 \mathrm{~km}^{3}\right)$ tsunami-triggering events, such as the $>3000 \mathrm{~km}^{3}$ Storegga Slide that occurred offshore Norway $\sim 8.2$ ka (Haflidason et al. 2005; Talling et al. 2014). Smaller landslides also pose a credible threat to seafloor infrastructure and coastal communities, particularly as they occur more frequently. Landslide volumes of $<<0.1 \mathrm{~km}^{3}$ triggered tsunamis offshore Nice (Dan, Sultan and Savoye 2007) and British Columbia (Skvortsov and Bornhold 2007) and resulted in landward retrogression leading to loss of life in Norway (Vardy et al. 2012). Even smaller failures of only 1.5- to 2-m thickness ruptured utility pipelines at several locations in Lake Mjøsa, Norway, causing damage of approximately $\$ 6.5$ million (Forsberg, Heyerdahl and Solheim 2016). The damage caused to offshore pipelines by submarine mass movements is estimated at > \$400 million per year (Mosher et al. 2010).

Turbidity currents are a potential hazard to seafloor infrastructure (Bruschi et al. 2006; Clare et al. 2015b) as they can transport large volumes of sediment (up to hundreds of cubic kilometres) at high velocities (up to $19 \mathrm{~m} / \mathrm{s}$; Piper, Cochonat and Morrison 1999) over thousands of kilometres (Talling et al. 2007). Longitudinal structures are most vulnerable to impacts including drag, loss of stability, undermining due to scour, or rupture (Parker et al. 2009; Clare et al. 2015b). Cable breaks by turbidity currents are well documented in many locations worldwide (Pope, Talling and Carter 2016; Pope et al. 2017), as well as localised pipeline ruptures (Syahnur and Jaya 2016). Given the potentially long-runout pathways of turbidity currents, avoidance by re-routing is typically impractical and economically unviable (Cooper, Wood and Andrieux 2013; Clare et al. 2015b).

Seabed sediment mobility induced by wind-driven, tidal, and thermohaline currents occurs in both shallow seas and deep oceans (Tom et al. 2016). Scour can be further enhanced by the emplacement of seafloor structures (Whitehouse et al. 2011; Harris et al. 2016; Figure 5D). Seafloor infrastructure in regions of mobile sediments must be designed with that in mind, due to potential exposure or undermining of buried foundations, development of free spans beneath pipelines, and excessive burial of thermally sensitive power cables (Besio et al. 2003, 2008; Emeana et al. 2016).

Fluid flow hazards manifest in many ways. Free gas in the sub-surface can modify sediment shear strength, compressibility, and effective stresses, thus affecting foundation design and slope stability (Chillarige et al. 1997; Evans 2010). Shallow gas can lead to gas kicks and blowouts while drilling, subsidence and leaks outside casing, and issues with cementing wells (Nimblett, Shipp and Strijbos 2005). Natural seepage of fluids at the seafloor ranges from kilometre-scale eruptive mud volcanoes with associated caldera collapses (Gray, Dingler and Wood 2013) to decametre-scale extrusion of asphalt at the seafloor formation, pockmarks, and authigenic bacteria-mediated carbonate crusts (Hovland, Gardner and Judd 2002; Jones et al. 2014). Fluid expulsion can create corrosive pore fluids and local modification of seafloor geotechnical properties (Thomas et al. 2011). These issues can lead to problems for pipeline design, particularly where seeps occur in high spatial densities (Gafeira, Long and Diaz-Doce 2012; Moss et al. 2012).

\section{How are marine geohazards typically assessed?}

Datasets acquired using conventional techniques (Figure 1) provide essential information on past events for geohazard assessments (Thomas et al. 2011; Vanneste et al. 2014). This may include the extent of landslide runout from sub-bottom profiling, past fluid flow sources from multi-beam data, and mapping of previous turbidity current pathways from side-scan sonar data. While advances are being made in data acquisition (Vardy et al. 2008; Soubaras and Dowle 2010; Campbell, Kinnear and Thame 2015), short-offset reprocessing (Vanneste et al. 2014), and inverse modelling to determine geotechnical properties (Vardy 2015; Vardy et al. 2017), interpretations based on these data only provide clues as to what happened in the past and not direct information on dynamic processes occurring in the present day. We face uncertainty when relying on the depositional record, as it may be incomplete due to erosion and reworking. To correctly interpret deposits, we also need to link them to a process. Typically, we rely on scaled-down laboratory experiments or theoretical models, but there are many uncertainties in such models due to lack of field- 

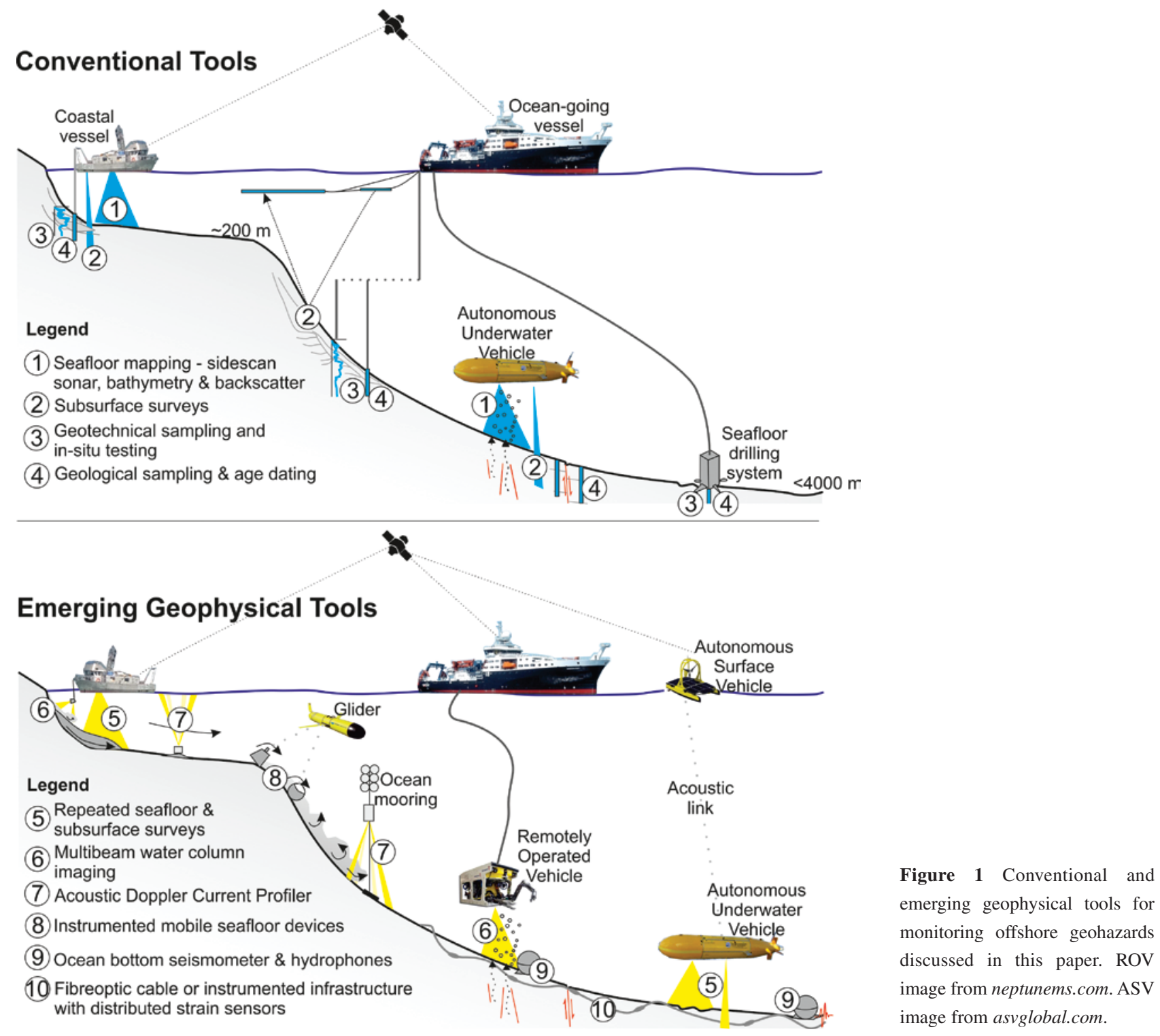

scale validation (Talling, Paull and Piper 2013; Talling et al. 2015). Therefore, many gaps remain in our understanding of marine geohazards, particularly in deep water (Table 1).

What can be learnt from direct monitoring in onshore settings?

Direct monitoring technology has been embraced onshore because of the relative ease of access and direct links to satellite communications (Hart and Martinez 2006). Direct monitoring of deepwater geohazards has been problematic due to (i) challenging environments and remote settings, which were previously prohibitively costly (Talling et al. 2013; Kelley, Delaney and Juniper 2014); (ii) technological issues related to positioning accuracy, data resolution, and communications (Hart and Martinez 2006; Hughes Clarke 2012); (iii) equipment limitations in measuring key parameters (e.g., measuring high concentration flows with acoustic instruments; Hughes Clarke 2016); and (iv) the often-destructive nature of geohazards that we wish to measure (e.g., Khripounoff et al. 2003). Geotechnical monitoring of offshore sites is becoming more commonplace, however, including the deployment of in-situ piezometers and tiltmeters to understand slope stability issues at specific locations (e.g., Richards et al. 1975; Prior and Suhayda 1979; Bennett et al. 1982; Sultan et al. 2004; Kvalstad et al. 2005; Strout and Tjelta 2005; Stegmann et al. 2011).

\section{EMERGING GEOPHYSICAL TOOLS FOR MONITORING ACTIVE MARINE GEOHAZARDS}

Recent technology advances now enable the first direct monitoring programmes of marine geohazards using geophysical tools. Here, we provide evidence from recent studies (Table 2) of how 
Table 1 Some outstanding questions that cannot be conclusively answered with conventional survey techniques.

\begin{tabular}{|c|c|c|c|}
\hline stability & Turbidity currents & $\begin{array}{l}\text { Scour and seafloor } \\
\text { sediment mobility }\end{array}$ & Fluid flow and shallow gas \\
\hline $\begin{array}{l}\text { - How does a slope evolve and } \\
\text { what are the preconditioning } \\
\text { factors for failure? } \\
\text { - What are the instantaneous } \\
\text { triggers or is failure delayed } \\
\text { (and what governs that delay)? } \\
\text { - How rapidly does slope failure } \\
\text { develop (seconds, minutes, } \\
\text { hours, days, years)? } \\
\text { - How does slope failure evolve } \\
\text { down-slope? } \\
\text { - What initial volumes are } \\
\text { involved and how much is } \\
\text { reworked later (e.g., by } \\
\text { currents)? }\end{array}$ & $\begin{array}{l}\text { - What are the triggers for flows? } \\
\text { - What is their frequency and how } \\
\text { appropriate is it to rely on age } \\
\text { dating? } \\
\text { - How representative are deposits of } \\
\text { the flows that emplaced them? } \\
\text { - Can we reconstruct flow properties } \\
\text { from deposits? } \\
\text { - What is the depth-resolved velocity } \\
\text { and sediment concentration profile } \\
\text { of a turbidity current? } \\
\text { How does that evolve through time, } \\
\text { and down-canyon? } \\
\text { How do turbidity currents interact } \\
\text { with the seafloor (and seafloor } \\
\text { structures)? }\end{array}$ & $\begin{array}{l}\text { - How and where does scour } \\
\text { initiate? } \\
\text { - What are the threshold } \\
\text { conditions required for onset } \\
\text { of scour? } \\
\text { - What is the rate of scour } \\
\text { development? } \\
\text { - How does scour morphology } \\
\text { evolve through time? } \\
\text { - How quickly is the evidence of } \\
\text { past scour removed by } \\
\text { sediment transport processes? }\end{array}$ & $\begin{array}{l}\text { - What is the rate and fluid flow at } \\
\text { the seafloor? } \\
\text { - How does flux vary through time? } \\
\text { - How is fluid flow affected by } \\
\text { external triggers? (e.g., tidal state, } \\
\text { seismic triggering) } \\
\text { - What and where are the present- } \\
\text { day migration pathways? } \\
\text { - How do pathways vary through } \\
\text { time? } \\
\text { How will it evolve and will it stay } \\
\text { in same place during lifetime of } \\
\text { development? } \\
\text { How representative is one seismic } \\
\text { profile to understand dynamic sub- } \\
\text { surface fluid flow processes? }\end{array}$ \\
\hline
\end{tabular}

Table 2 Overview of direct geophysical monitoring studies detailed in this paper. Italicised text refers to non-marine but relevant studies.

\begin{tabular}{|c|c|c|c|c|}
\hline \multicolumn{2}{|c|}{ Geophysical tool [and specifications where reported] } & \multirow{2}{*}{$\begin{array}{l}\begin{array}{l}\text { Location [and water depth } \\
\text { where appropriate] }\end{array} \\
\text { Oguué River submarine delta, Gabon } \\
{[<55 \mathrm{~m}]}\end{array}$} & \multirow{2}{*}{$\begin{array}{l}\text { Process observed } \\
\begin{array}{l}\text { Submarine landslide } \\
\text { and gulley incision }\end{array}\end{array}$} & \multirow{2}{*}{$\begin{array}{l}\text { Reference } \\
\text { Biscara et al. } \\
\text { (2012) }\end{array}$} \\
\hline \multirow{6}{*}{ 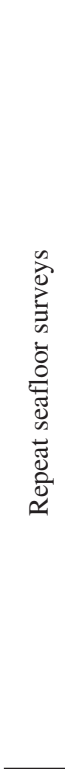 } & $\begin{array}{l}5 \mathrm{x} \text { annual surveys (2004-2008) vessel-mounted } \\
\text { single-beam echo sounder, } 2009 \text { vessel-mounted } \\
\text { multi-beam [10-m bin size] }\end{array}$ & & & \\
\hline & $\begin{array}{l}2 \mathrm{x} \text { vessel-mounted (in } 2008 \text { and 2012) multi-beam } \\
\text { echo sounder [1-m bin size] }\end{array}$ & $\begin{array}{l}\text { Begawan Solo submarine delta, East } \\
\text { Java }[<30 \mathrm{~m}]\end{array}$ & Turbidity currents & $\begin{array}{l}\text { Syahnur and Jaya } \\
\text { (2016) }\end{array}$ \\
\hline & $\begin{array}{l}6 \text { x surveys; } 1967 \text { and } 1974 \text { vessel-mounted single- } \\
\text { beam echo sounder [5- to } 20 \text {-m bin size]; vessel- } \\
\text { mounted multi-beam echo sounder } 1991 \text { (10-m bin } \\
\text { size), } 1999 \text { and } 2006 \text { [2-m bin size] and } 2011 \text { [1-m } \\
\text { bin size] }\end{array}$ & $\begin{array}{l}\text { Offshore Nice, France } \\
{[<300 \mathrm{~m}]}\end{array}$ & Submarine landslides & Kelner et al. (2016) \\
\hline & $\begin{array}{l}\text { Survey every 6-24 months (from } 2004 \text { to } 2009 \text { ); } \\
\text { survey every week day (during Spring and Summer } \\
2011 \text { and 2012). Vessel-mounted multi-beam echo } \\
\text { sounder [ }<0.5-\mathrm{m} \text { bin size] }\end{array}$ & $\begin{array}{l}\text { Squamish submarine delta, British } \\
\text { Columbia, Canada }[<200 \mathrm{~m}]\end{array}$ & $\begin{array}{l}\text { Delta-lip collapses and } \\
\text { turbidity currents }\end{array}$ & $\begin{array}{l}\text { Hughes Clarke et } \\
\text { al. }(2012,2014), \\
\text { Clare } \text { et al. } \text { (2016), } \\
\text { Hughes Clarke } \\
\text { (2016) }\end{array}$ \\
\hline & $\begin{array}{l}7 \mathrm{x} \text { vessel-mounted multi-beam echo sounder over } \\
29 \text { months [2- to 3-m bin size] }\end{array}$ & $\begin{array}{l}\text { Monterey Canyon, California, USA } \\
{[<300 \mathrm{~m}]}\end{array}$ & $\begin{array}{l}\text { Submarine landslide, } \\
\text { bedform migration }\end{array}$ & Smith et al. (2007) \\
\hline & $\begin{array}{l}\text { Repeat vessel-mounted multi-beam echo sounder } \\
\text { survey every } 15 \text { minutes for } 10 \text { days }[<0.5 \text {-m bin } \\
\text { size] }\end{array}$ & $\begin{array}{l}\text { Westerschelde Estuary, The } \\
\text { Netherlands }[<20 \mathrm{~m}]\end{array}$ & $\begin{array}{l}\text { Dredging-induced slope } \\
\text { failure, bedform } \\
\text { migration }\end{array}$ & $\begin{array}{l}\text { Mastbergen et al. } \\
\text { (2016) }\end{array}$ \\
\hline \multirow{6}{*}{ 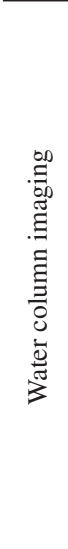 } & $\begin{array}{l}\text { 50- and } 180-\mathrm{kHz} \text { vessel-mounted multi-beam echo } \\
\text { sounder }\end{array}$ & $\begin{array}{l}\text { North Sea }[90 \mathrm{~m}] \text { and Dnepr Shelf, } \\
\text { Black Sea }[240]\end{array}$ & Fluid flow & $\begin{array}{l}\text { Von Deimling et al. } \\
\text { (2007) }\end{array}$ \\
\hline & $12.5-\mathrm{kHz}$ vessel-mounted multi-beam echo sounder & $\begin{array}{l}\text { Cascadia Margin, Offshore Oregon, } \\
\text { USA [500-700 m] }\end{array}$ & Fluid flow & $\begin{array}{l}\text { Heeschen et al. } \\
(2003)\end{array}$ \\
\hline & $\begin{array}{l}\text { 18-, 38-, and } 120-\mathrm{kHz} \text { vessel-mounted split-beam } \\
\text { echo sounder }\end{array}$ & North-west Svalbard [240 m] & Fluid flow & Veloso et al. (2015) \\
\hline & $\begin{array}{l}\text { Vessel-mounted multi-beam echo sounder - } \\
\text { unknown frequency }\end{array}$ & Bosphorus Strait, Black Sea [90 m] & Saline underflow & Hiscott et al. (2013) \\
\hline & $\begin{array}{l}\text { 500-kHz M3 sonar. [Update rate } 0.5 \text { seconds; } \\
\text { Range } 35-150 \mathrm{~m} \text {; } 2 \text { - to } 10-\mathrm{cm} \text { resolution] }\end{array}$ & $\begin{array}{l}\text { Squamish submarine delta, British } \\
\text { Columbia, Canada }[<200 \mathrm{~m}]\end{array}$ & Turbidity currents & $\begin{array}{l}\text { Hughes Clarke } \\
\text { (2016), Hage et al. } \\
(2016)\end{array}$ \\
\hline & $\begin{array}{l}\text { 500-kHz M3 sonar. [Update rate } 0.5 \text { seconds; } \\
\text { Range } 35-150 \mathrm{~m} \text {; } 2 \text { - to } 10-\mathrm{cm} \text { resolution] }\end{array}$ & $\begin{array}{l}\text { Westerschelde Estuary, The } \\
\text { Netherlands }[<20 \mathrm{~m}]\end{array}$ & $\begin{array}{l}\text { Dredging-induced } \\
\text { turbidity current }\end{array}$ & $\begin{array}{l}\text { Mastbergen et al. } \\
\text { (2016); Clare } \text { et al. } \\
(2015 b)\end{array}$ \\
\hline
\end{tabular}




\begin{tabular}{|c|c|c|c|c|}
\hline \multicolumn{2}{|r|}{ Geophysical tool [and specifications where reported] } & \multirow{2}{*}{$\begin{array}{l}\text { Location [and water depth } \\
\text { where appropriate] }\end{array}$} & \multirow{2}{*}{$\begin{array}{l}\text { Process observed } \\
\text { Dredging-induced } \\
\text { sediment plumes and } \\
\text { tidally induced currents }\end{array}$} & \multirow{2}{*}{$\begin{array}{l}\text { Reference } \\
\text { Van Lancker and } \\
\text { Baeye (2015) }\end{array}$} \\
\hline \multirow{5}{*}{ 己े } & $\begin{array}{l}300-\mathrm{kHz} \text { ADCP mounted on surface glider [bin size } \\
2 \mathrm{~m} \text { ] }\end{array}$ & & & \\
\hline & $\begin{array}{l}\text { 300-kHz ADCP on deep-water mooring [bin size } 2 \\
\mathrm{~m}]\end{array}$ & $\begin{array}{l}\text { Congo Canyon, offshore Angola } \\
{[2000 \mathrm{~m}]}\end{array}$ & Turbidity currents & $\begin{array}{l}\text { Cooper } \text { et al. } \\
\text { (2013) }\end{array}$ \\
\hline & $\begin{array}{l}3 \times 300-\mathrm{kHz} \text { ADCPs on deep-water moorings } \\
\text { [Average of } 60 \text { one-second pings every hour; } 2-\mathrm{m} \\
\text { bin size] }\end{array}$ & $\begin{array}{l}\text { Monterey Canyon, California, USA } \\
{[820-1445 \mathrm{~m}]}\end{array}$ & $\begin{array}{l}\text { Turbidity currents and } \\
\text { internal tides }\end{array}$ & $\begin{array}{l}\text { Xu et al. }(2004, \\
2014), \text { Symons } \text { et } \\
\text { al. }(2017)\end{array}$ \\
\hline & $600-\mathrm{kHz}$ towed ADCP [0.5-m bin size] & Bosphorus Strait, Black Sea $[<80 \mathrm{~m}]$ & Saline underflow & $\begin{array}{l}\text { Parsons et al. } \\
(2010)\end{array}$ \\
\hline & $\begin{array}{l}\text { 1200-kHz ADCP seafloor frame-mounted (upward } \\
\text { facing) [10-ping ensemble every } 4 \text { seconds, } 25-\mathrm{cm} \\
\text { bin size] }\end{array}$ & $\begin{array}{l}\text { Squamish submarine delta, British } \\
\text { Columbia, Canada }[<200 \mathrm{~m}]\end{array}$ & Turbidity currents & $\begin{array}{l}\text { Hughes Clarke } \\
\text { (2016), Hage } \text { et al. } \\
\text { (2016) }\end{array}$ \\
\hline \multirow{4}{*}{ 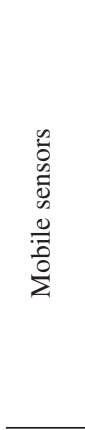 } & $\begin{array}{l}\text { Acoustic ranging between seafloor nodes. [Daily } \\
\text { measurement of } 20 \text { acoustic interrogations from } 3 \\
\text { nodes to } 4 \text { sensors with a precision of } \pm 3 \mathrm{~mm} \text { ] }\end{array}$ & $\begin{array}{l}\text { Offshore Santa Barbara Basin, } \\
\text { California, USA [330-420 m] }\end{array}$ & Slope creep & Blum et al. (2010) \\
\hline & $\begin{array}{l}\text { 45-kg blocks with Homer beacons and smart } \\
\text { boulders located via acoustic communications with } \\
\text { surface vessel }\end{array}$ & $\begin{array}{l}\text { Monterey Canyon, California, USA } \\
{[\sim 280 \mathrm{~m} \text { to } 1500 \mathrm{~m}]}\end{array}$ & Turbidity currents & $\begin{array}{l}\text { Paull et al. (2010), } \\
\text { Sullivan (2015) }\end{array}$ \\
\hline & $\begin{array}{l}\text { 30-kg concrete blocks located with water column } \\
\text { imaging }\end{array}$ & $\begin{array}{l}\text { Squamish submarine delta, British } \\
\text { Columbia, Canada }[<200 \mathrm{~m}]\end{array}$ & Turbidity currents & $\begin{array}{l}\text { Hughes Clarke et } \\
\text { al. (2014) }\end{array}$ \\
\hline & $\begin{array}{l}\text { "Smart-clast" installed into a glacier measuring } \\
\text { pressure, temperature, tilt. Data collected six times } \\
\text { daily. Located using radio links }\end{array}$ & $\begin{array}{l}\text { Briksdalsbreen glacier, Norway [ } 80 \\
m \text { below ice level] }\end{array}$ & $\begin{array}{l}\text { Glacier movement and } \\
\text { deformation }\end{array}$ & $\begin{array}{l}\text { Martinez et al. } \\
\text { (2005) }\end{array}$ \\
\hline 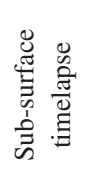 & $\begin{array}{l}\text { Repeat reflection seismic survey (Chirp and } \\
\text { Boomer with 5- to 10-m line separation) }\end{array}$ & Offshore West Scotland [12 m] & $\begin{array}{l}\text { Fluid flow from } \mathrm{CO}_{2} \\
\text { injection }\end{array}$ & $\begin{array}{l}\text { Blackford et al. } \\
\text { (2014) }\end{array}$ \\
\hline \multirow{5}{*}{ 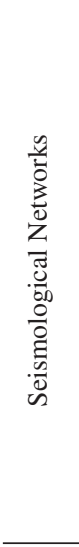 } & $\begin{array}{l}\text { Passive seismological network of eleven stations } \\
\text { deployed } 15-200 \mathrm{~m} \text { from the stream. [Up to } 80-\mathrm{Hz} \\
\text { bandwidth; 200-Hz sampling rate] }\end{array}$ & $\begin{array}{l}\text { Alpine stream "Torrent de St Pierre", } \\
\text { French Alps }\end{array}$ & $\begin{array}{l}\text { Bedload transport in a } \\
\text { stream }\end{array}$ & Burtin et al. (2011) \\
\hline & $\begin{array}{l}5 \mathrm{x} \text { three-component broadband ocean bottom } \\
\text { seismometers [0.0027- to } 50-\mathrm{Hz} \text { bandwidth } \\
\text { and } 100-\mathrm{Hz} \text { sampling rate] } \\
\end{array}$ & $\begin{array}{l}\text { Tyrrhenian Sea, Mediterranean }[1500 \\
\text { m] }\end{array}$ & $\begin{array}{l}\text { Volcanic degassing, } \\
\text { submarine landsliding, } \\
\text { earthquake seismicity }\end{array}$ & $\begin{array}{l}\text { Sgroi et al. }(2009 \text {, } \\
\text { 2014) }\end{array}$ \\
\hline & $4 \mathrm{x}$ moored hydrophones $[1000-\mathrm{Hz}$ bandwidth] & $\begin{array}{l}\text { West Mata volcano, Lau Basin, near } \\
\text { Tonga }[230 \mathrm{~m}]\end{array}$ & Submarine landslides & $\begin{array}{l}\text { Caplan-Auerbach } e t \\
\text { al. (2014) }\end{array}$ \\
\hline & Terrestrial broadband seismic network & Southern Taiwan & $\begin{array}{l}\text { Terrestrial landslides } \\
\text { and possible submarine } \\
\text { slumping }\end{array}$ & Lin et al. (2010) \\
\hline & Moored hydrophone & Offshore West Scotland [12 m] & $\begin{array}{l}\text { Monitoring rate of } \mathrm{CO}_{2} \\
\text { leakage at seafloor } \\
\text { following injection }\end{array}$ & $\begin{array}{l}\text { Blackford et al. } \\
\text { (2014) }\end{array}$ \\
\hline \multirow{3}{*}{ 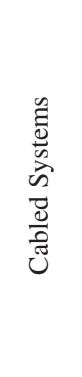 } & $\begin{array}{l}\text { Commercial fibre-optic network } \\
\text { [events detected from timing of cable breaks] }\end{array}$ & $\begin{array}{l}\text { Grand Banks, offshore } \\
\text { Newfoundland }[<2500 \mathrm{~m}]\end{array}$ & $\begin{array}{l}\text { Earthquake-triggered } \\
\text { landslide and turbidity } \\
\text { current }\end{array}$ & $\begin{array}{l}\text { Heezen and Ewing } \\
\text { (1952), Piper } \text { et al. } \\
(1999)\end{array}$ \\
\hline & $\begin{array}{l}\text { Commercial fibre-optic network } \\
\text { [events detected from timing of cable breaks] }\end{array}$ & $\begin{array}{l}\text { Gaoping Canyon, offshore Taiwan } \\
{[4500 \mathrm{~m}]}\end{array}$ & $\begin{array}{l}\text { Earthquake and tropical } \\
\text { storm-triggered } \\
\text { turbidity currents }\end{array}$ & $\begin{array}{l}\text { Carter et al. (2012, } \\
\text { 2014), Gavey et al. } \\
(2016)\end{array}$ \\
\hline & $\begin{array}{l}\text { Commercial fibre-optic network } \\
\text { [events detected from timing of cable breaks] }\end{array}$ & Global database & $\begin{array}{l}\text { Earthquake and tropical } \\
\text { storm-triggered } \\
\text { submarine landslides } \\
\text { and turbidity currents }\end{array}$ & $\begin{array}{l}\text { Pope et al. (2016, } \\
\text { 2017) }\end{array}$ \\
\hline
\end{tabular}




\begin{tabular}{|c|c|c|c|c|}
\hline \multicolumn{2}{|c|}{ Geophysical tool [and specifications where reported] } & \multirow{2}{*}{$\begin{array}{l}\text { Location [and water depth } \\
\text { where appropriate] } \\
\text { Offshore San Diego, California, USA } \\
{[1100 \mathrm{~m}]}\end{array}$} & \multirow{2}{*}{$\begin{array}{l}\text { Process observed } \\
\text { Seafloor displacements } \\
\text { such as slope creep and } \\
\text { temperature shifts due } \\
\text { to fluid flow }\end{array}$} & \multirow{2}{*}{$\begin{array}{l}\text { Reference } \\
\text { Blum et al. (2008) }\end{array}$} \\
\hline \multirow{7}{*}{ 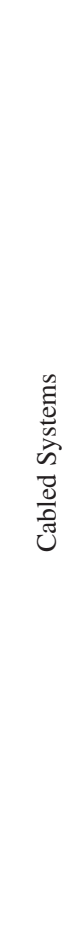 } & $\begin{array}{l}\text { Bespoke fibre-optic cable; strain measured by an } \\
\text { Electronic Distance Meter [spatial resolution } \pm 1 \\
\text { mm over }<10 \mathrm{~km} \text {; strain resolution }<1 \mu \varepsilon \text { ] }\end{array}$ & & & \\
\hline & $\begin{array}{l}\text { Bespoke fibre-optic cable to measure strain with } \\
\text { embedded sensors [spatial } 1 \text {-cm resolution over } \\
\text { tens of metres, strain resolution }>2 \mu \varepsilon \text { ] }\end{array}$ & $\begin{array}{l}\text { Cables in trench above tunnel, } \\
\text { London, UK }\end{array}$ & Ground displacement & $\begin{array}{l}\text { Hauswirth et al. } \\
\text { (2014) }\end{array}$ \\
\hline & $\begin{array}{l}\text { Bespoke distributed fibre-optic stress sensing [10- } \\
\text { cm spatial resolution, over } 0.5 \mathrm{~km} \text {; stress resolution } \\
0-15 \mathrm{MPa},]\end{array}$ & Yangtze Province, China & Terrestrial landsliding & Dai et al. (2008) \\
\hline & $\begin{array}{l}\text { Bespoke fibre-optic to measure temperature }[1-\mathrm{m} \\
\text { spatial resolution over } 30 \mathrm{~km} \text {; temperature } \\
\left.\text { resolution }<0.01{ }^{\circ} \mathrm{C}\right]\end{array}$ & Lake Geneva, France/Switzerland & Lake bed temperature & Selker et al. (2006) \\
\hline & $\begin{array}{l}\text { Bespoke fibre-optics deployed on pipeline [2-m } \\
\text { spatial resolution over } 25 \mathrm{~km} ; 0.1{ }^{\circ} \mathrm{C} \text { temperature } \\
\text { resolution; strain resolution }>2 \mu \varepsilon ; \text { measurement } \\
\text { range }<150 \mathrm{~km}]\end{array}$ & $\begin{array}{l}\text { Cabled sensors installed on buried } \\
\text { pipeline in Italy }\end{array}$ & Temperature and strain & $\begin{array}{l}\text { Inaudi and Glisic } \\
\text { (2007) }\end{array}$ \\
\hline & $\begin{array}{l}\text { Ocean Observatory Initiative and Ocean Networks } \\
\text { Canada [ }>1700 \mathrm{~km} \text { of cable } 14 \text { subsea terminals, } \\
\text { 10-Gbs communication link, hundreds of } \\
\text { instruments] }\end{array}$ & $\begin{array}{l}\text { Juan de Fuca Ridge, East Pacific } \\
\text { Ocean }[<2800 \mathrm{~m}]\end{array}$ & $\begin{array}{l}\text { Volcanic activity, } \\
\text { earthquake seismicity, } \\
\text { near-bed currents, fluid } \\
\text { flow, slope instability }\end{array}$ & $\begin{array}{l}\text { Kelley et al. (2014), } \\
\text { Delaney and Kelley } \\
\text { (2015) }\end{array}$ \\
\hline & $\begin{array}{l}\text { Victoria Experimental Network Under the Sea } \\
\text { (VENUS) [1-tonne instrumented platform } \\
\text { connected by 10-GBs cabled communication link] }\end{array}$ & $\begin{array}{l}\text { Fraser River, British Columbia, } \\
\text { Canada }[<300 \mathrm{~m}]\end{array}$ & $\begin{array}{l}\text { Near-bed currents, slope } \\
\text { instability, turbidity } \\
\text { currents }\end{array}$ & $\begin{array}{l}\text { Lintern and Hill } \\
\text { (2010), Lintern } e t \\
\text { al. (2016) }\end{array}$ \\
\hline
\end{tabular}

direct monitoring tools can address key uncertainties for geohazard assessment, including repeat surveys, water column imaging, acoustic Doppler current profiling, mobile seafloor devices, and cabled networks.

\section{How dynamic is the seafloor?}

Modern multi-beam systems provide near $100 \%$ coverage to create digital elevation models (DEMs) of the seafloor (Hughes Clarke et al. 2012). By calculating the difference between two successive surveys, seafloor changes above the resolution limits of the initial surveys can be quantified. "DEM of Difference" maps show areas of sediment accumulation and erosion and no change between surveys (e.g., Fox, Chadwick and Embley 1992; Lane, Richards and Chandler 1994; Smith et al. 2007; Wheaton et al. 2010; Conway et al. 2012). Wheaton et al. (2010) provided detailed discussions on the development of the technique and uncertainty quantification. This approach has been used for bedform migration, scour, fault displacement, slope instability, and sediment transport (Schimel et al. 2015 and the many references cited therein). Its effectiveness depends upon (i) the rate of the process(es) governing change in relation to the timeframe of repeat surveys and (ii) the scale of seafloor change(s) in relation to the limit of detection (Smith et al. 2007).

High rates of seafloor change have been revealed in several settings. Annual surveys at the submarine Ogooué River Delta, Gabon between 2004 and 2009 revealed sub-annual slope failures ( $<2.5$ million cubic metres; Biscara et al. 2012; Figure 2A).
Slope failures were attributed to sediment over-loading and slope over-steepening, but could not be conclusively linked based on the data available (Biscara et al. 2012). It is estimated that it would take less than 20 years from inception to infill and mask the largest slide scar based on sediment accumulation rates (Biscara et al. 2012). Thus, smaller landslide scars may form and become infilled between annual surveys and be missed entirely.

Repeat surveys at the submarine prodelta of the Bengawan Solo River, East Java revealed a highly active system (Syahnur and Jaya 2016). While the frequency of events could not be determined between only two surveys (2008 and 2012), compelling evidence of turbidity current activity was revealed by incised gullies in the upper slope and deposited lobes at their termini (Figure 3E). More frequent surveys are thus needed to pinpoint triggers and understand the rate of geohazards (e.g., Kelner et al. 2016).

Perhaps the most intensively re-surveyed marine location is the Squamish submarine delta in British Columbia, Canada. The delta front progrades, on average, $4 \mathrm{~m}$ per year (Hickin 1989); however, the seafloor change on the prodelta slope is anything but steady. Ninety-three daily seafloor surveys in 2011 revealed that the delta lip may prograde tens of metres within only a few days following peaks in river discharge, before reaching a critical point for stability, with measured failure volumes of up to $150,000 \mathrm{~m}^{3}$ (Hughes Clarke et al. 2012; Clare et al. 2016; Figure 2B). The seafloor evidence for delta-lip failures can be entirely masked within days to weeks by rapid sediment accumulation. More than 100 turbidity currents were also detected based on changes within submarine 
channels (e.g., Figure 3F). The high temporal resolution of repeat surveys at Squamish pinpointed triggering mechanisms for slope instability (pore pressure changes) and turbidity currents (seaward flushing of delta-top sediments during low tides; Clare et al. 2016). A similar tidally driven process was previously identified and measured at the nearby Fraser Delta (Ayranci et al. 2012; Lintern, Hill and Stacey 2016). It is estimated that more than $90 \%$ of submarine deposits are reworked by turbidity currents on the Squamish Prodelta; therefore, the fidelity of deposits recovered by geological core sampling will be low (Hughes Clarke, Marques and Pratomo 2014). This reworking is important as core samples are often used to determine frequency and magnitude of geohazards (Thomas et al. 2010). The recurrence of turbidity currents or thickness of land- slide deposits in similar settings could thus be under-reported based on sedimentary evidence, at least by an order of magnitude.

Recent advances have been made in using repeat reflection seismic surveys to image and quantify change in the sub-surface, to complement repeat seafloor surveys. For example, the pathway and position of fluid migration was successfully tracked over several days following a controlled injection of $\mathrm{CO}_{2}$ (Blackford et al. 2014). Repeated surveys can document the evolution of dynamic sub-surface conditions such as pore pressure, which can inform slope stability assessments. A considerable number of issues must be considered, however, when comparing seismic profiles at different time steps, including trace-totrace source consistency, positioning accuracy, resolution

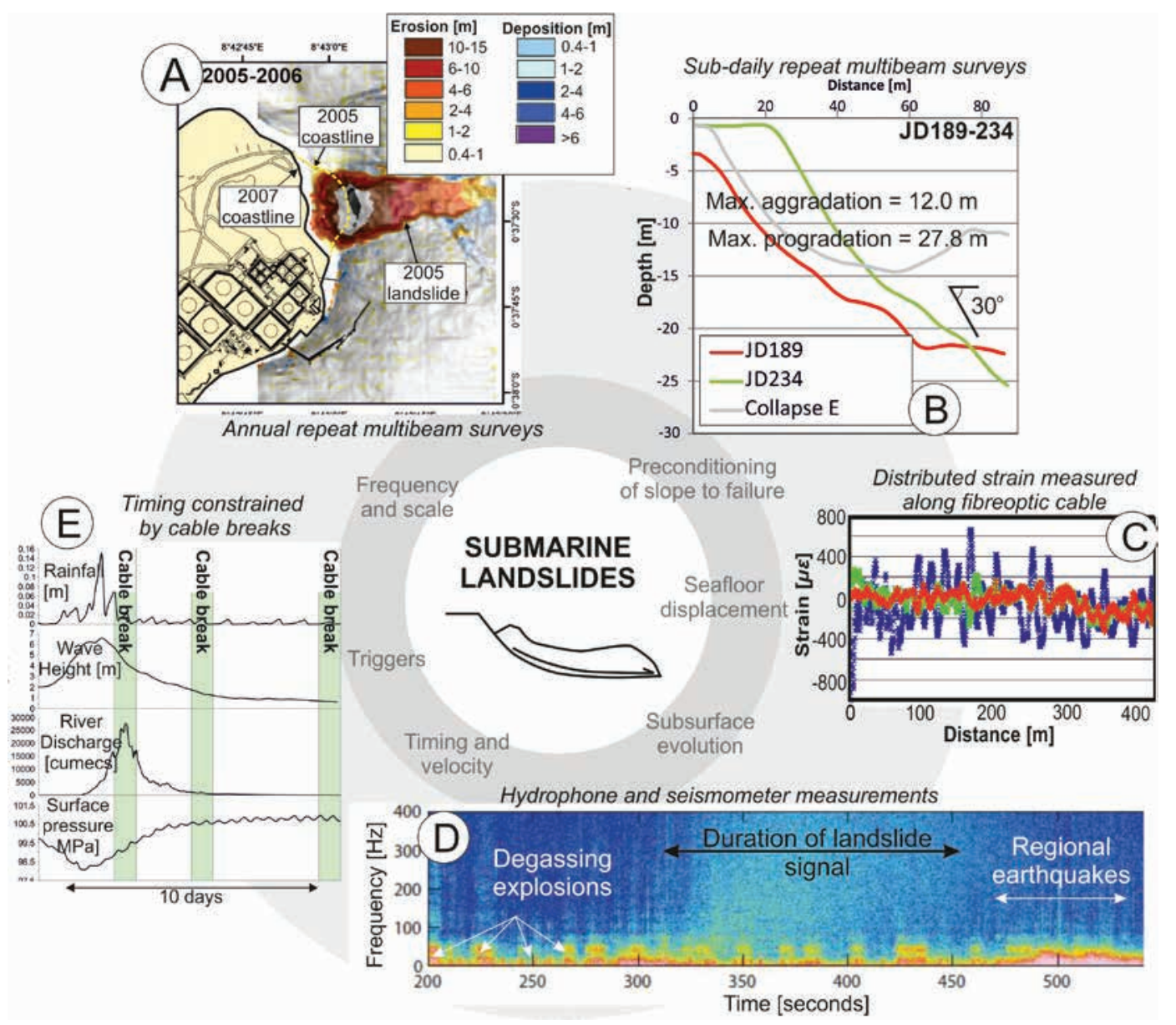

Figure 2 Examples of emerging geophysical tools that can address key uncertainties (grey text) concerning submarine landslide hazard. (A) Difference of DEMs offshore Gabon between 2005 and 2006 illustrating large submarine slide that resulted in retrogression of coastline (modified from Biscara et al. (2012)). (B) Seafloor profiles showing dramatic short-term variations in bathymetry on the Squamish submarine delta slope, British Columbia. JD refers to Julian Day (modified from Clare et al. (2016)). (C) Fibre-optic sensors deployed along a section of an onshore pipeline (SMARTape sensors). Strain was measured along three parallel lines on the pipeline, at 20 micro-strain resolution, and spatial resolution of $1.5 \mathrm{~m}$ (modified from Inaudi and Glisic (2007)). (D) Spectrograms of one hydrophone from West Mata volcano, Lau Basin. The signal between 310 and $450 \mathrm{~s}$ is interpreted as a landslide, identified by its broadband spectrum and changing frequency content (modified from Caplan-Auerbach et al. (2014)). (E) Mass movements identified from seafloor telecommunication cable breaks in the Gaoping Canyon, Taiwan that are linked to tropical-cyclone-related triggers (modified from Pope et al. (2017)). 
limitations, accurate depth imaging, and environmental noise (Table 3).

What does water column imaging reveal about geohazards? Split-beam and multi-beam sonars can be used to make measurements within the water column as well as the seafloor. Water column imaging provides valuable information for hydrocarbon exploration and gas bubble detection (e.g., Heeschen et al. 2003; Von Deimling, Brockhoff and Greinert 2007) and is typically deployed from a moving platform such as a survey vessel or a remotely operated underwater vehicle (ROV) (e.g., Hiscott et al. 2013). To determine seafloor fluid flow hazard, it is necessary to

Table 3 Some considerations for techniques discussed in this paper in order to directly monitor deep-water geohazards.

\begin{tabular}{|c|c|}
\hline Technique & Considerations for deep-water deployment \\
\hline $\begin{array}{l}\text { Repeat seafloor } \\
\text { surveys }\end{array}$ & $\begin{array}{l}\text { - High vertical and horizontal accuracy not possible from vessel-mounted systems in deep water } \\
\text { - AUV- or ROV-based platforms required to acquire multi-beam data closer to seabed } \\
\text { - Steep slopes may inhibit high-resolution imaging - forward- or side-looking multi-beam surveying may be required (can be } \\
\text { mounted on both AUV and ROV) } \\
\text { - AUV and ROV systems require acoustic communication to another system for accurate positioning (e.g., surface vessel and } \\
\text { seafloor nodes) to enable creation of accurate DEM of Difference maps } \\
\text { - Seafloor surveying does not image the process, only the resultant topography } \\
\text { - Timing of surveys must be more regular than the rate of the process to be measured }\end{array}$ \\
\hline $\begin{array}{l}\text { Water column } \\
\text { imaging }\end{array}$ & $\begin{array}{l}\text { - The deeper the water, the slower the ping rate for vessel-based systems } \\
\text { - Imaging is better when stationary at one site, or moving slowly, but this compromises the area that can be covered } \\
\text { - Preferably image closer to seafloor on a platform; hence, ROV- or AUV-based systems are ideal } \\
\text { - Imaging is power intensive; hence, having an integral power supply is ideal (e.g., umbilical link from ROV to a vessel or } \\
\text { cabled link to a fixed seafloor observatory connected to power supply) } \\
\text { - Future developments in battery efficiency may improve the capacity of AUV platforms and moored deployment. May be pos- } \\
\text { sible to have an option for instrument to sit in "idle" low-power mode that can be switched on to full power by an external } \\
\text { trigger (e.g., acoustic communication) }\end{array}$ \\
\hline Current profiling & $\begin{array}{l}\text { - Seafloor-based systems (e.g., upward-looking ADCP in tripod) can be buried or damaged } \\
\text { - Moorings can be dragged and damaged; hence, mooring design needs to be designed carefully (e.g., for turbidity currents, } \\
\text { heavy weight, streamlined thin wire, and sufficient buoyancy are needed to maintain a rigid mooring) } \\
\text { - Dense sediment flows inhibit penetration of acoustic signals, resulting in blanking of the data and lack of information near the } \\
\text { seafloor } \\
\text { - Data closest to seafloor are jeopardised by the effects of side-lobe interference. Typically, the lower two bins of data are } \\
\text { obscured by this effect } \\
\text { - Multiple moorings may be needed to understand how events such as turbidity currents evolve down-canyon } \\
\text { - Multiple frequency instruments may be required to understand sediment concentration as grain size and concentration have } \\
\text { similarly important effects on acoustic backscatter }\end{array}$ \\
\hline $\begin{array}{l}\text { Mobile seafloor } \\
\text { sensors }\end{array}$ & $\begin{array}{l}\text { - Sensors can be damaged by the processes that are measured } \\
\text { - Retrieval of sensors can be difficult, especially if they are buried } \\
\text { - Direct transfer of measured information inhibited by bandwidth limits of acoustic transmission; therefore, it is currently only } \\
\text { possible to track location and not download data }\end{array}$ \\
\hline $\begin{array}{l}\text { Seismological } \\
\text { networks }\end{array}$ & $\begin{array}{l}\text { - High-frequency seismic noise may be generated by a number of different processes } \\
\text { - Diagnosing the signal of specific geohazards is challenging, and calibration is required against known events }\end{array}$ \\
\hline $\begin{array}{l}\text { Timelapse sub- } \\
\text { surface } \\
\text { monitoring }\end{array}$ & $\begin{array}{l}\text { - Repeatability at all scales, from gross survey geometry to trace/trace source consistency, is critical } \\
\text { - For repeat grids of two-dimensional profiles, positioning accuracy needs to be better than the first Fresnel zone, and density } \\
\text { of line spacing controls the horizontal resolution of change that can be imaged } \\
\text { - For repeat high-resolution 3D seismic volumes (4D surveys), positioning needs to be better than a quarter of the source wave- } \\
\text { length (in X, Y, and Z), and source/receiver mid-point spacing controls the horizontal resolution } \\
\text { - Vertical resolution is controlled primarily by the source frequency bandwidth } \\
\text { - Multiple Sound Velocity Profile (SVP) drops will be required to capture changes in the water column velocity that will alter } \\
\text { arrival times and therefore cause apparent changes in sub-surface structure } \\
\text { - Unless data are accurately depth imaged, apparent sub-surface structural changes between surveys can be caused by subtle } \\
\text { changes in acoustic velocity as well as physical changes in structure } \\
\text { - Quantitative comparison between surveys (impedance, velocity, attenuation, etc.) will require extremely good repeatability } \\
\text { and therefore is likely to be strongly weather dependent for towed deployment }\end{array}$ \\
\hline $\begin{array}{l}\text { Fibre-optic } \\
\text { sensors }\end{array}$ & $\begin{array}{l}\text { - Existing fibre-optic network may allow for real-time measurements of strain and temperature; however, there are commercial } \\
\text { and political sensitivities in using those data for monitoring } \\
\text { - Network may be vulnerable to damage by geohazards, but passive deployment to "listen" for geohazards may be possible } \\
\text { - Tension due to deployment and other processes needs to be factored out of strain calculations }\end{array}$ \\
\hline
\end{tabular}




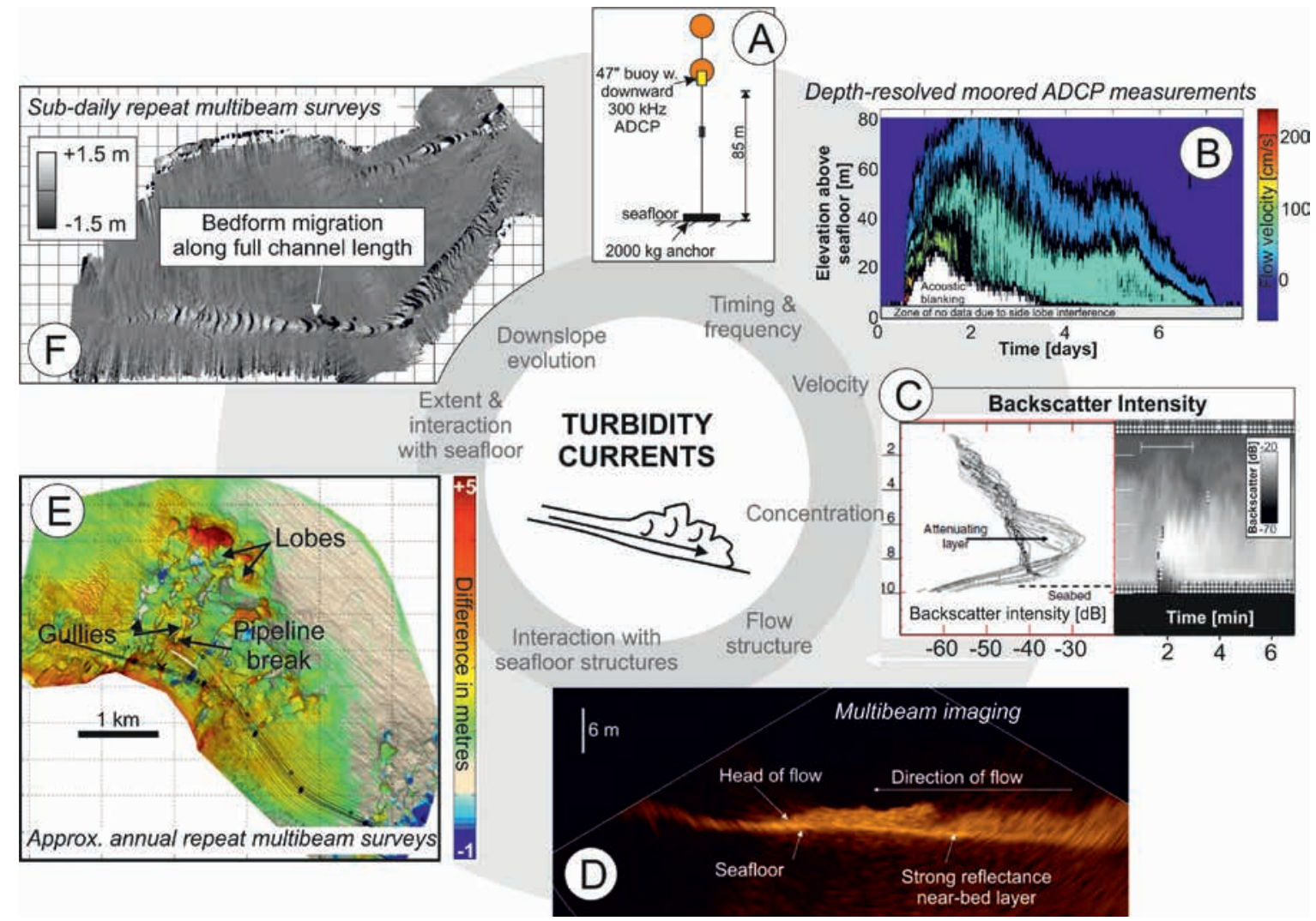

Figure 3 Examples of emerging geophysical tools that can address key uncertainties (grey text) concerning turbidity current hazard. (A) Example deepwater moored ADCP configuration. (B) Time-series velocity plot of one turbidity current that lasted several days recorded in the deep-water (2000 $\mathrm{m}$ ) Congo Canyon (Cooper et al. 2012) by a down-looking moored 300-kHz ADCP. (C) Moored down-looking ADCP measurements of backscatter intensity for a turbidity current on the Squamish submarine delta (modified from Hughes Clarke (2016)). Stacked backscatter profiles are from a 7-minute window at the start of the flow annotated as a white line on time-series plots shown to the right. (D) M3 multi-beam sonar image (down-looking, $3^{\circ}$ beam) showing the arrival of a dredging-induced turbidity current, which appears to be stratified with a highly reflective basal layer underlying a more bilious, turbulent layer (modified from Clare et al. (2015b)). (E) Difference of DEM at the Bengawan Solo Prodelta, East Java between 2008 and 2012 (modified from Syahnur and Jaya (2016)). Depositional lobes and erosional gullies are clearly seen. Pipelines including one that was damaged by a sediment flow cross the area of gullies. (F) Difference of DEM for the Squamish submarine delta between two consecutive days (modified from Clare et al. (2016)).

understand where active seeping occurs as well as its extent and temporal variability (Figure 4). Hill et al. (2011) outlined a risk assessment ranking fluid flow from low (gentle bubbling) to high hazard (eruptions of gas and sediment). Water column imaging can pinpoint release points and quantify flow rates and bubble release intensity for such assessments. A compromise must be made between covering a large area (fast sailing speed) and providing high-resolution water column imaging that is less degraded by ship noise (slow sailing speed; i.e., < 5 knots; Veloso et al. 2015). The visual representation of gas bubbles is strongly affected by vessel speed, as well as currents that can deflect the trajectory of rising bubbles, and the acoustic insonification of bubbles (Veloso et al. 2015). Two-phased approaches may be appropriate for many sites, with an initial but relatively fast water column survey to first identify areas that are most prone to fluid flow, such as delta fronts, pockmarks, faults, and where gassy sediments are identified. Subsequent detailed monitoring, using a slower pass with a ship, ROV, or mooring, can provide detailed data on seep activity and density. When designing monitoring campaigns, it is important to consider that expulsion rates may also vary temporally. In-situ monitoring using an optical flow meter offshore California revealed expulsion rates at cold seeps ( $950 \mathrm{~m}$ in water depth) were affected by tidal elevation (LaBonte, Brown and Tryon 2007). Fluid flow may also be transiently accelerated by other processes, including earthquakes and slope creep (Hovland et al. 2002; LaBonte et al. 2007). Thus, fully understanding the hazard posed by fluid flow may require longer-term monitoring.

Multi-beam water column imaging can also be used to measure processes that suspend and transport sediment, such as turbidity currents. For instance, a 500-kHz Kongsberg M3 multi-beam sonar was used to image turbidity currents triggered by dredging activity offshore Holland (Mastbergen et al. 2016). A relatively thin flow $(<6 \mathrm{~m})$ is shown in Figure 3D; however, for much 
thicker flows, or those with higher sediment concentrations, it may not be possible to penetrate the seafloor with this acoustic technique (Clare et al. 2015b). Hughes Clarke (2016) used multiple multi-beam sonars concurrently to image the interaction of flows with trains of crescent-shaped bedforms at the Squamish Prodelta, using vertical profile and planform views. Seven discrete flows were recorded in a two-hour period alone. Analysis of planform time series revealed that turbidity current flow fronts were typically moving at $\sim 2 \mathrm{~m} / \mathrm{s}$, occasionally surging up to $3 \mathrm{~m} / \mathrm{s}$. Vertical profiles showed that flows tended to thin and accelerate on the steep lee side of bedforms and thicken and decelerate on the stoss sides. One flow, featuring a distinct acoustically attenuated basal layer, caused lee-side erosion and stoss-side deposition. This dynamic seafloor interaction explains the repeated nature of erosion and deposition observed from repeated seafloor surveys (Figure 3F). Six of the flows caused no discernible change, however. Thus, the frequency of flows determined from seafloor elevation changes alone is also likely to be under-recorded. In order to reliably image through thick and/or high sediment concentration flows, it may be necessary to use lower frequencies that suffer less from attenuation and scattering. Future developments in turbidity current monitoring might include tools more routinely used for shallow sub-surface imaging. Recent field tests at the Squamish submarine delta have demonstrated the validity of using a parametric Chirp system to image the seafloor: turbidity current interface (Clare et al. 2015b; Hage et al. 2016). Chirp sub-bottom profilers are small, relatively lightweight seismic reflection systems with low power consumption (therefore suitable for longterm deployment) and a typical operational bandwidth of 1-24 $\mathrm{kHz}$ (Vardy et al. 2008). The source waveform is highly repeatable and can be easily customised, allowing the source to be tuned to provide optimum imaging for the specific target and environment (Schock and LeBlanc 1990; Gutowski et al. 2002). Experimental laboratory-scale work has also shown that electrical resistivity tomography (ERT) may be a useful technique to consider in future field-scale applications (Schlaberg et al. 2006; Clare et al. 2015b). ERT is capable of measuring sediment concentrations of up to $65 \%$ by volume, which is significantly beyond the limits of conventional concentration meters ( 20\%; Sleath 1991).

\section{What can acoustic Doppler current profilers measure other than oceanographic currents?}

Acoustic Doppler current profilers (ADCPs) are routinely used for oceanographic current monitoring. An ADCP measures current velocities over a specified depth range by using the Doppler shift of the backscattered acoustic signal (Griffiths and Flatt 1987; Wilson et al. 1997). Three beams allow for measurements of the three-dimensional (3D) velocity field, with the fourth beam allowing for an estimate of measurement error. The echo intensity response of each beam can be converted into acoustic backscatter by correcting for noise attenuation and, hence, provides information on suspended sediment, which has become commonplace in riverine, estuarine, and coastal studies (e.g.,
Thorne, Hardcastle and Soulsby 1993; Reichel and Nachtnebel 1994; Holdaway et al. 1999; Rennie, Millar and Church 2002; Gartner 2004; Kostaschuk et al. 2005 and references therein).

Recently, ADCPs have been used to make the first depth and time-resolved measurements of turbidity currents, to define key parameters that have not been constrained accurately before (Talling et al. 2013). These key parameters govern the nature and magnitude of impact by flows on seafloor infrastructure and include flow thickness (e.g., Xu 2010; Cooper et al. 2013), internal velocity structure (Xu, Noble and Rosenfeld 2004), and sediment concentration (Xu, Sequeiros and Noble 2014; Hughes Clarke 2016). Upward-looking instruments such as those deployed from a seabed frame have yielded useful data but can be buried or damaged by large flows (e.g., Inman et al. 1976; Hughes Clarke et al. 2012). The most successful deployment has been moored, down-looking ADCPs, secured with a heavy wire rope, high buoyancy floats, and heavy anchor weights (Figure 3A; e.g., Xu 2010, 2011; Cooper et al. 2013; Xu, Barry and Paull 2013; Xu et al. 2014), but these may still move to some degree. For example, a deep-water mooring in the Monterey Canyon was deflected and moved down-canyon $580 \mathrm{~m}$ by an approximately $3-\mathrm{m} / \mathrm{s}$ turbidity current, during a period of less than 20 minutes (Symons et al. 2017).

While many studies have documented long recurrence times (hundreds to thousands of years) for turbidity currents (Wynn et al. 2014), potentially damaging flows can be very frequent in some settings. More than 11 turbidity currents were recorded in a period of less than 7 months in the deep-sea Congo Canyon ( 2000 m in water depth; Cooper et al. 2013). These flows reached thicknesses of more than $80 \mathrm{~m}$, lasted up to 10 days, with an average velocity of $\sim 1 \mathrm{~m} / \mathrm{s}$ (Cooper et al. 2013; Figure 3B). A turbidity current was passing by the Congo Canyon mooring for $\sim 20 \%$ of its deployment within the deep-sea canyon. ADCP measurements at the Squamish submarine delta revealed the velocity structure and thickness of the same turbidity observed by M3 sonars (Hughes Clarke 2016). Flow velocities at the Squamish site were of a similar magnitude to those in the Congo Canyon; however, the duration of flows was much shorter (minutes to hours; Hughes Clarke 2016). Not all turbidity currents that caused bedform migration ran-out the full length of the northern submarine channel at Squamish, with only 22 of the 49 events recorded by an ADCP at its distal end (Hughes Clarke et al. 2012; Clare et al. 2016).

Two main issues exist with respect to using ADCPs for measuring near-bed properties of a turbidity current. First, if a flow is too dense, acoustic signals may not be able to penetrate the flow, causing "blanking". Second, data closest to seafloor are often jeopardised by the effects of side-lobe interference, which typically affects $\sim 6 \%$ of the height above seafloor (Sumner and Paull 2014; RDI Instruments 2015; Clare et al. 2015b). In the case of the Congo Canyon data, the lower two bins of data are obscured by this effect (Cooper et al. 2013). This means that any features in the first few metres above seafloor cannot be imaged. Thus, it 


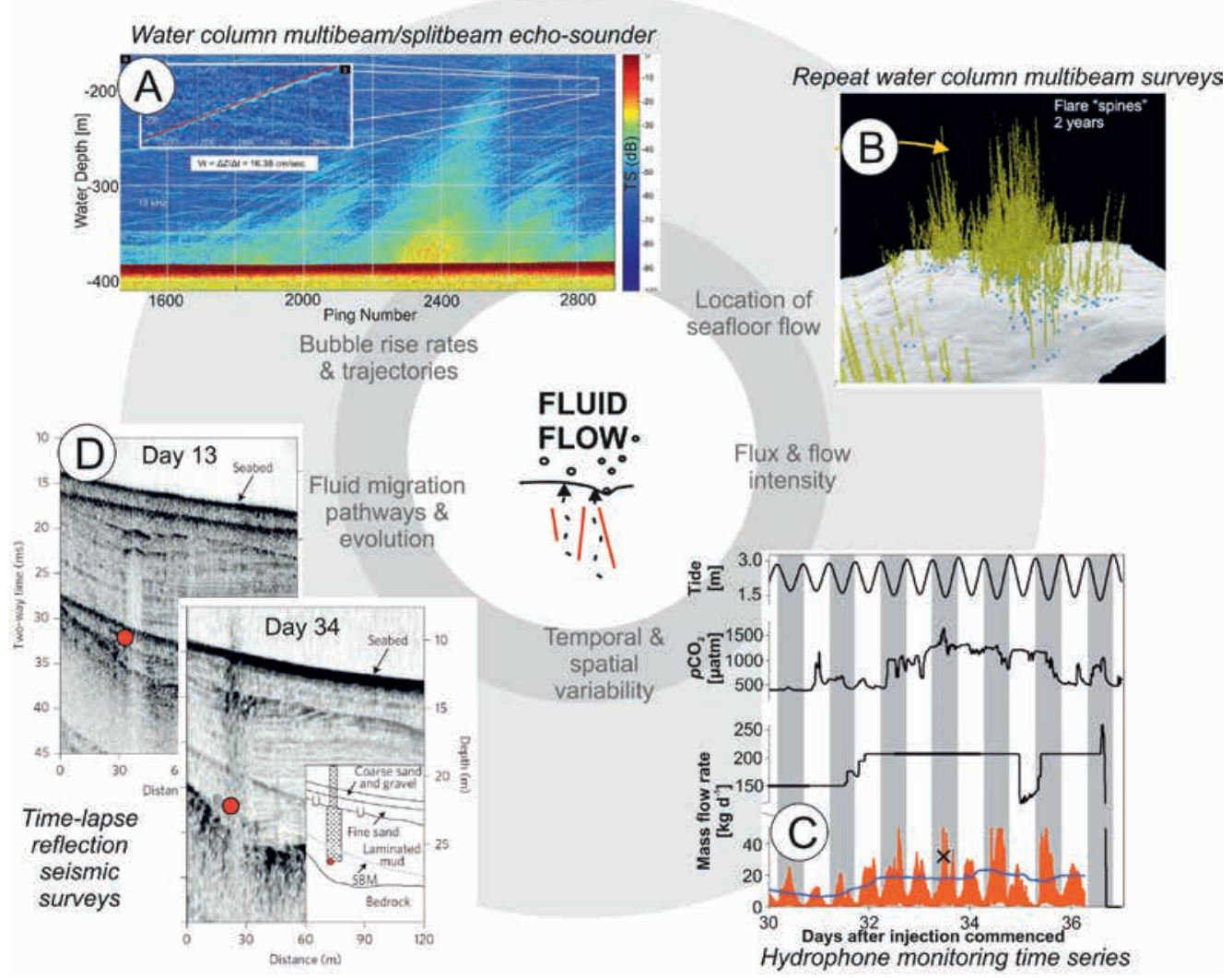

Figure 4 Examples of emerging geophysical tools that can address key uncertainties (grey text) concerning sub-surface fluid flow and seafloor expulsionrelated hazard. (A) Echogram from offshore NW Svalbard, focussing on bubble rise rates captured during slow mode sampling. Colours represent target strength (modified from Veloso et al. (2015)). (B) 3D view of gas flare spines from split-beam echo sounding in approximately 250-m water depth offshore NW Svalbard (modified from Veloso et al. (2015)). (C) Gas injection rate, hydrophone-determined seabed flux, and carbonate system variations in the water column over multiple tidal cycles during later stages of injection (modified from Blackford et al. (2014)). (D) Repeat seismic reflection profiles from Day 13 and Day 34 (modified from Blackford et al. (2014)) illustrating migration of injected $\mathrm{CO}_{2}$. Day 13 images a bright spot (free gas) at depth, whereas Day 34 survey images enhanced sub-surface reflectivity above that depth and acoustic turbidity in the water column.

is important that such data are acquired in tandem with other techniques if dense flows are anticipated, and it is necessary to understand what is happening at the seafloor-flow interface.

\section{What do mobile sensors tell us about geohazards?}

When built appropriately for the environment in question, wireless sensor nodes (termed "envinodes" by Hart and Martinez (2006)) can provide measurements of their interaction with geohazards. Blum et al. (2010) attempted to quantify whether instability was ongoing in the vicinity of seafloor scarp-like cracks between two previous slope failures in the offshore Santa Barbara Basin, California. Acoustic ranging on a seafloor network of nodes and transponders identified that no significant motion $(< \pm 7 \mathrm{~mm})$ occurred over 2 years; thus, the slope was concluded to be stable. Mobile nodes deployed on the seafloor can provide information about the interactions at the base of turbidity currents that cannot presently be resolved from acoustic instruments such as ADCPs and multi-beam sonars. Understanding this near-bed interaction is of particular relevance to seafloor-hosted infrastructure. Initial field trials in Monterey Canyon involved deployment of three 45-kg concrete blocks fitted with acoustic Homer beacons (Paull et al. 2010). Instrumented blocks were partially embedded into the seafloor using an ROV and tracked intermittently from 2007 to 2008 in order to determine any movement. At least six periods of movement were detected, with the blocks transported up to $1.7 \mathrm{~km}$ down-canyon during 26 months of re-surveying (Paull et al. 2010). As the beacons continued to function throughout, it was suggested that the blocks moved by translation at or within the shallow seafloor, rather than tumbling (Paull et al. 2010; Talling et al. 2013). A similar experiment was performed at the Squamish submarine delta, where six $\sim 30-\mathrm{kg}$ concrete blocks were deployed with three attached air-filled spheres (Hughes Clarke et al. 2014). Rather than tracking a beacon, an automated algorithm was used to identify the spheres from water column imaging performed over 93 successive week days. Seafloor elevation change from the previous survey was noted on 52 of those 93 days; however, blocks were only displaced on 8 days, with observed movements of between 12 and $253 \mathrm{~m}$ (Hughes Clarke et al. 2014). The precise reason for why some events moved blocks and others did not is unclear. Hughes Clarke et al. (2014) suggested that any clear indication from the 
seafloor data may be smeared by the effects of subsequent currents and reworking.

Innovative solutions are being developed to not just track movement of blocks but also determine the nature and rate of their movement. Like the deployment of small envinodes within glaciers that track movement and deformation (Martinez, Hart and Ong 2004), smart boulders have recently been deployed in the Monterey Canyon by the Monterey Bay Aquarium Research Institute to measure pressure, acceleration, and rotation during sediment transport events (Sullivan 2015). Previous studies have relied upon opportunistic or sporadic surveys to communicate with mobile envinodes (e.g., Paull et al. 2010); however, advancements in autonomous marine technology have spawned long-endurance, low power-use platforms such as gliders and solar-powered autonomous surface vessels (ASVs) that can provide an improved near-continuous acoustic link between the seafloor device and a shore-based receiver (Favali and Beranzoli 2006; Wynn et al. 2014; Van Lancker and Baeye 2015; Figure 1).
What does seismic noise tell us about marine geohazards? Seismometers are typically used for earthquake monitoring, but processes other than earthquakes can create seismic noise. Burtin et al. (2011) deployed a passive onshore seismological network on the banks of an Alpine river and used spectral analysis of highfrequency $(>1 \mathrm{~Hz})$ seismic noise to differentiate water from a bedload signal, which was consistent with independent hydrological monitoring. A similar approach may be suitable in marine settings for remotely sensing submarine debris flows or turbidity currents using instruments placed on interfluves, rather than within a channel axis where they would be damaged by the direct impact of a flow. This same premise may also hold for monitoring submarine landslides and fluid flow. Analysis of data from broadband ocean-bottom seismometers (OBSs) in the southern Tyrrhenian Sea revealed not only earthquake-related seismicity but also low-frequency seismicity events related to volcanic degassing and submarine landsliding (Sgroi et al. 2014). Similar interpretations have been made from moored hydrophones offshore the West Mata volcano in the Lau Basin near Tonga (Caplan-Auerbach et

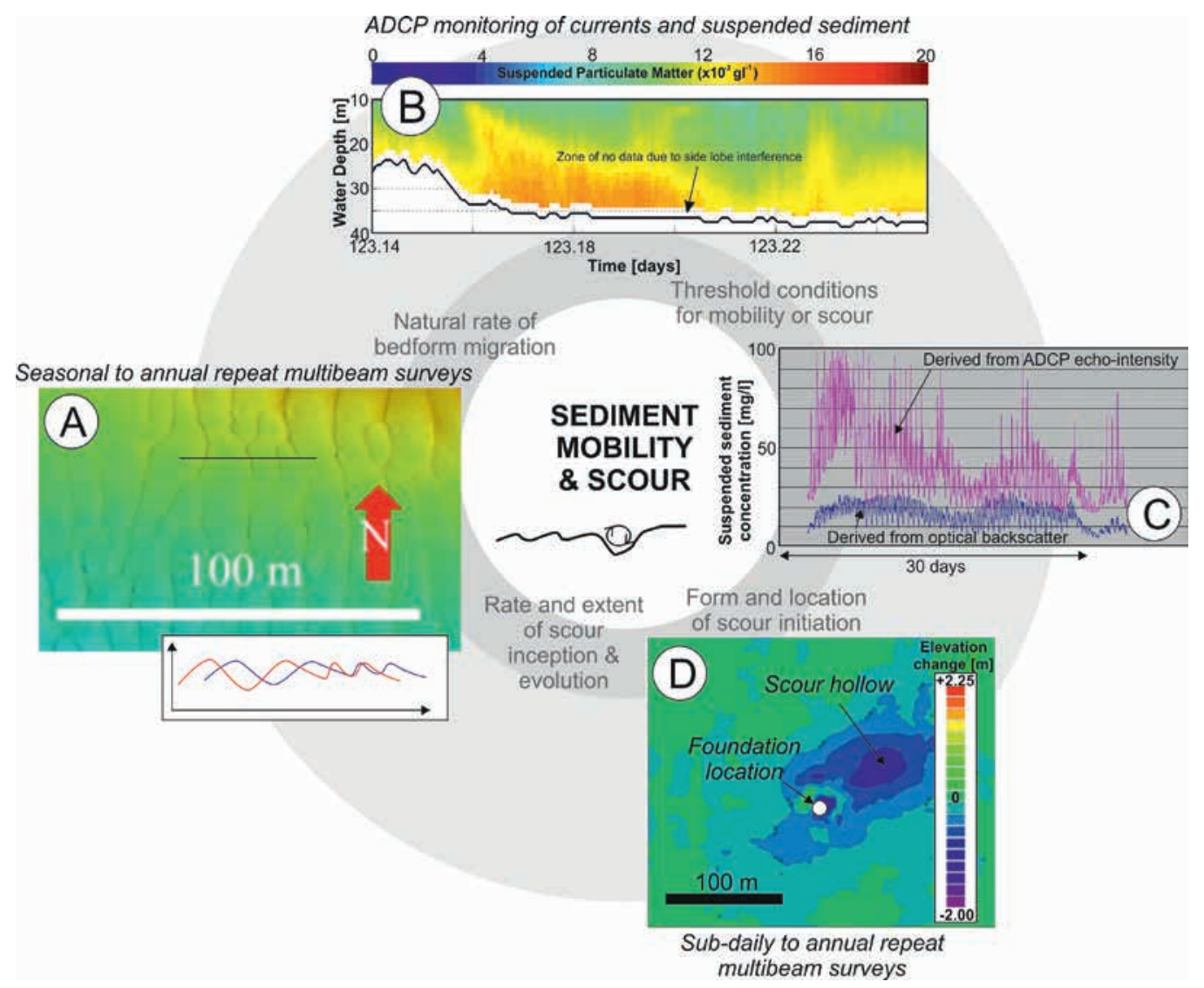

Figure 5 Examples of emerging geophysical tools that can address key uncertainties (grey text) concerning sediment mobility and scour hazard. (A) Tidal seafloor bedforms from multi-beam survey offshore Holland with an example shown of seafloor profiles from two repeated surveys highlighting natural bedform migration. (B) Estimation of suspended particulate matter concentration in the North Sea, based on backscatter intensity from a downlooking ADCP fixed to a moving surface glider (modified from Van Lancker and Baeye (2015)). (C) Estimation of suspended sediment concentration from an ADCP and optical backscatter in the North Sea (modified from ABPmer Ltd et al. (2010)). (D) Repeated multi-beam survey around a seafloor foundation illustrating scour development (modified from ABPmer Ltd et al. (2010)). 
al. 2014; Figure 2D). Submarine landslides, triggered by volcanic activity, were identified by their weak and strong powers at specific frequencies generated by multipathing of sound waves. Analysis of frequency data from the moorings indicates that landslides travelled at speeds of 10-25 m/s (Caplan-Auerbach et al. 2014). A shore-based broadband seismic network in Taiwan that was designed to monitor terrestrial landslide activity recorded up to 52 offshore seismic events, interpreted to relate to slope failures that occurred in or near the submarine Gaoping Canyon (Lin et al. 2010). If this method can be validated, it should provide a useful tool for future hazard assessment for the dense networks of offshore infrastructure in the region around Taiwan.

\section{Existing and bespoke cabled networks}

What can be learnt from the existing global telecommunication cable network?

The global network of seafloor telecommunication cables is susceptible to damage at multiple locations by marine hazards, including earthquakes, tropical cyclones, submarine landslides, and turbidity currents (Heezen and Ewing 1952; Piper et al. 1999; Carter et al. 2012; Gavey et al. 2016; Pope et al. 2016, 2017). Information on past cable breaks provides useful information for future infrastructure routing strategies, as well as constraints on the hazard responsible for the damage. For instance, the 1929 Grand Banks submarine landslide was linked to a $M_{w} 7.2$ earthquake trigger based on the timing of cable breaks. The speed of the resultant turbidity current (up to $19 \mathrm{~m} / \mathrm{s}$ ) was also determined from multiple sequential cable ruptures several hundred kilometres downslope (Piper et al. 1999). Based on analysis of a global database of cable breaks Pope et al. (2016) found that that there was no obvious earthquake magnitude, which will consistently trigger a submarine mass flow. They identified that sediment supply and topography were as, or more, important as the intensity of seismicity for triggering cable-breaking flows. Analysis of timing of cable breaks in the same global database also revealed that tropical cyclones did not necessarily trigger flows at their peak due to cyclic loading of shelf sediments. Instead, cyclones often result in plunging river water that lags behind a rainfall peak by hours or delayed submarine slope failures that occur several days after the sudden emplacement of sediment near the head of a submarine canyon (Pope et al. 2017; Figure 2E).

\section{Distributed measurements along fibre-optic networks}

One key, but outstanding, question is why some fast-moving turbidity currents only break some of the cables along their path. For instance, fast (5-8 m/s) flows broke cables in the Gaoping Canyon, but intervening cables also survived (Gavey et al. 2016). The answer may be provided in the future by the distributed measurement of parameters determined from the analysis of light scattering (Rayleigh, Brillouin, or Raman) from optical fibres within these cables (Blum, Nooner and Zumberge 2008). Measurements can be made by sending a series of optical pulses down the fibre and recording the response of the naturally occurring optical scat- tering signals as a function of time, thus accessing all points along the fibre (Belal and Newson 2012). The fibre can be used both as a transducer and a signal communication link. It is therefore possible to quantify the strain to which a cable is subjected at specific locations by individual flows and the cumulative effects of successive impacts, thus understanding why some cables broke and others did not. Commercial sensitivities currently limit access to this information for most cables, but bespoke fibre-optic systems could be deployed to make such measurements. Legacy cables have been successfully used to make distributed measurements of lake bed temperature across Lake Geneva (Selker et al. 2006).

Optical fibres can also be employed as passive monitoring devices. Thus, it is possible, and potentially advantageous, to deploy fibre-optic networks out of the direct path of geohazards (e.g., on interfluves or canyon terraces) to "listen" for damaging submarine landslide or turbidity current activity. Fibre-optic systems are routinely used to provide structural health checks on onshore hydrocarbon pipelines, to identify the early stages of possible leaks in remote areas using strain and temperature sensing (Inaudi and Glisic 2007; Figure 2C). The same technology could be deployed on the seafloor, or fixed to existing offshore infrastructure, to make low-power, long-term continuous monitoring of geohazard timing, triggers, and rates. Encapsulation of the silica fibre-optic core and its cladding in polymer coatings not only renders the fibre robust and ready for use in harsh environments but also makes it easy to handle. Fibre-optic sensors are a promising technology to increase the inspection efficiency and accuracy for seafloor infrastructure prone to impacts by geohazards, due to their durability, stability, small size, and distributed probing capabilities (Alahbabi, Cho and Newson 2006; Belal and Newson 2010; Masoudi, Belal and Newson 2013). Future monitoring could include identification of warmer subsurface fluid expulsion, cumulative strain applied by recurrent sediment flows, or displacement by steady ground movement.

\section{Cabled sensor networks}

Fibre-optic cables can also be used to relay signals from extrinsic sensors and to connect to receivers over high-bandwidth connections (Kelley et al. 2014; Favali, Beranzoli and De Santis 2015). The use of distributed sensor networks enables real-time data analysis over large time and spatial scales (Delaney and Kelley 2015). A major advantage of these networks is high-fidelity data streaming, with focussed long-endurance monitoring at multiple locations; however, cables and sensors are susceptible to damage (e.g., Inman, Nordstrom and Flick 1976; Prior et al. 1987; Williams et al. 1988; Paull et al. 2010; Carter et al. 2014; Khripounoff et al. 2003; Talling et al. 2013 and references therein; Symons et al. 2017), and a balance needs to be struck to get close enough to make measurements without losing equipment. Bornhold, Ren and Prior (1994) and Talling et al. (2013) provided guidance in minimising the potential for damage of instruments. The VENUS system at the submarine Fraser Delta, British Columbia includes two platform nodes equipped with ADCPs, turbidity sensors, sector scanning 
sonar, video camera, CTD probe, and acoustic Doppler velocimeters (Lintern and Hill 2010; Lintern et al. 2016). This spread of instrumentation would be otherwise unfeasible on long-term autonomous moored deployment due to power constraints. One of the instrumented platforms ( 1000 kg in water), located outside of a submarine channel, was toppled by an unconfined turbidity current event. The platform instrumentation continued to make measurements as it tumbled, until the connecting armoured cable was broken. As the data were transmitted in real time, follow-up surveys could be rapidly mobilised, which demonstrated that there was only minor modification to the seafloor ( $0.3-0.7 \mathrm{~m}$ vertical change) even though the flow had a speed of 7 and $9 \mathrm{~m} / \mathrm{s}$ (Lintern et al. 2016). These platforms have since been modified to withstand such forces and are measuring turbidity currents on a regular basis (pers. comm. Gywn Lintern).

\section{DISCUSSION}

Advances in technologies that have been tested in relatively shallow water now enable a new wave of direct monitoring for marine geohazards in deep water. With this step change in technology came the first detailed measurements of controls, rates, and mechanics governing a wide range of seafloor and sub-surface processes. Hence, what are the key learnings for geohazard assessment?

\section{Timing is everything}

The timescale and rapidity of repeat surveys must be designed in relation to the rate of the natural process(es) being monitored. Relatively large landslide scars may be entirely reworked within years (Biscara et al. 2012), and smaller-scale seafloor features can be lost within hours or days (Hughes Clarke 2016). At the Squamish Prodelta, seafloor changes were noted between surveys spaced only 15 minutes apart (Hughes Clarke 2016). Hence, seafloor change identified between two or three annual surveys will not accurately capture all events in such dynamic settings. Furthermore, to tie events to preconditioning or triggering factors, a higher temporal constraint is necessary than can be afforded by repeat surveys. In-situ measuring devices, such as ADCPs, OBSs, or fibre-optic cables, can provide that accuracy and have provided the first constrained tie of turbidity currents with their triggers (e.g., Pope et al. 2016, 2017; Lintern et al. 2016) and quantification of tidal controls of fluid flow (e.g., Blackford et al. 2014).

A common feature of slope failures, identified from both cable breaks and ADCP measurements, appears to be that they are often delayed after some event, such as the passage of a tropical cyclone (e.g., offshore Taiwan) or sudden dumping of sediment offshore by a river flood (e.g., British Columbia fjords). The delay is thought to relate to inhibited dissipation of pore pressures but would not have been identified without the high temporal constraint from direct monitoring (Clare et al. 2016; Pope et al. 2017).

\section{Precise positioning is essential}

High temporal resolution is key to understanding triggers, but knowing exactly where those measurements were taken is as important. Errors in horizontal positioning during seafloor or sub-surface surveys result in uncertainty as to whether the difference between surveys is caused by some natural process or is an artefact. Major forward steps have been made in accurate positioning and geodesy for analysis of repeat surveys in relatively shallow water, in some cases enabling confident vertical resolution of seafloor change to $<0.1 \mathrm{~m}$ (e.g., Hughes Clarke et al. 2012; Schimel et al. 2015).

As the resolution of multi-beam echo sounding is water depth dependent, vessel-mounted surveying leads to poor-quality repeat seafloor surveys in deep water. It is particularly important to have a high degree of accuracy, as several studies have identified that slope failures may be relatively widespread areally, but only very thin (tens of centimetres; Moernaut et al. 2015; McHugh et al. 2016). Slope failures with such limited relief will be near impossible to determine from hull-mounted seafloor surveys in shallow water, let alone in deep water. The advent of underwater autonomous platforms, including AUVs, has led to extremely high resolution seafloor and sub-surface surveys that are capable of such resolution; however, the positioning accuracy of such systems in isolation is limited. Where the seafloor can be proven to be stationary, it may be possible to georeference the survey to known features. Most sites that feature active geohazards, however, do not have a static seafloor. Thus, innovations in acoustic communications need to be adopted so that the AUV can triangulate its location in relation to seafloor nodes or seasurface-based systems such as ASVs (Figure 1).

\section{Powerful and damaging events may not necessarily be recorded in the sedimentary record}

A cautionary message from recent monitoring is that conventional geological techniques may underestimate both the frequency and magnitude of marine geohazards in some situations. For instance, Lintern et al. (2016) showed that a damaging turbidity current at the Fraser Delta did not cause significant seafloor change. Less than 0.3 to $0.7 \mathrm{~m}$ of erosion and deposition occurred, despite a flow of up to $9 \mathrm{~m} / \mathrm{s}$ interacting with the seafloor. Thus, one should be careful as to what is interpreted from multi-beam or side-scan sonar data alone. Repeat surveys at the Squamish Prodelta indicate that the $>90 \%$ of sediments deposited by turbidity currents are reworked by subsequent flows; hence, analysis of sediment cores from the site would indicate at least an order of magnitude fewer events. It is also important to note that databases of cable breaks do not record all flows, only those that resulted in damage; intervening cables may survive (Gavey et al. 2016). Hence, any of these datasets (seafloor, sediment cores, and cable breaks) has the potential to provide misleading inputs to a risk assessment.

\section{CONCLUSIONS}

We have outlined a number of emerging techniques that address key uncertainties concerning several marine geohazards that could not be achieved with conventional techniques. It is now 
possible to make direct measurements of deep-sea turbidity currents, quantify the rate of seafloor mobility, constrain the controls on slope instability, and measure the flux of seafloor fluid expulsion. There are limitations to direct monitoring, however (Table 3 ). The recurrence time of many marine geohazards may be far too long to be caught by such monitoring techniques (Corbett et al. 2014). It is highly unlikely that we will observe processes on the scale of the Storegga Slide during a 1- to 3-year monitoring campaign. Measurements of smaller-scale but highly recurrent events can still provide useful insight into understanding larger processes. Many infrastructure impact assessments are based on laboratory-scale models, which suffer from scaling issues (Talling et al. 2013). By making measurements of real events in the deep sea, we can provide calibration and testing of these numerical models, even if the process observed is not at its maximum scale. Further work is needed to understand how relatively small but frequent geohazard events relate to the very large, infrequent ones (Corbett et al. 2014). This can only be achieved by integrating direct measurements with longer-term records from seismic profiles and sediment coring. Direct monitoring should therefore be deployed in a complementary manner alongside conventional techniques where environmental conditions call for it and to provide enhanced confidence to geohazard assessments.

\section{ACKNOWLEDGEMENTS}

Clare, Cartigny, and Talling acknowledge funding from the Natural Environment Research Council (NERC), including "Environmental Risks to Infrastructure: Identifying and Filling the Gaps" (NE/P005780/1) and "New field-scale calibration of turbidity current impact modelling" (NE/P009190/1). The authors also acknowledge discussions with collaborators as part of Talling's NERC International Opportunities Fund grant (NE/ M017540/1) "Coordinating and pump-priming international efforts for direct monitoring of active turbidity currents at global test sites". Talling was supported by a NERC and Royal Society Industry Fellowship hosted by the International Cable Protection Committee. Gwyn Lintern and an anonymous reviewer are thanked for their helpful reviews.

\section{REFERENCES}

ABPmer Ltd et al. 2010. A further review of sediment monitoring data. Commissioned by COWRIE Ltd (project reference ScourSed-09).

Alahbabi M.N., Cho Y.T. and Newson T.P. 2006. Long-range distributed temperature and strain optical fibre sensor based on the coherent detection of spontaneous Brillouin scattering with in-line Raman amplification. Measurement Science and Technology 17(5), 10821090.

Ayranci K., Lintern D.G., Hill P.R. and Dashtgard S.E. 2012. Tidesupported gravity flows on the upper delta front, Fraser River delta, Canada. Marine Geology 326, 166-170.

Belal M. and Newson T.P. 2010. Enhanced performance of a temperature-compensated submeter spatial resolution distributed strain sensor. IEEE Photonics Technology Letters 22(23), 1705-1707.

Belal M. and Newson T.P. 2012. Experimental examination of the variation of spontaneous Brillouin power and frequency coefficients under the combined influence of temperature and strain. Journal of Lightwave Technology 99, 1250-1255

Bennett R.H., Burns J.T., Clarke T.L., Faris J.R., Forde E.B. and Richards A.F. 1982. Piezometer probes for assessing effective stress and stability in submarine sediments. In: Marine Slides and Other Mass Movements, pp. 129-161. Springer US.

Besio G., Blondeaux P., Brocchini M. and Vittori G. 2003. Migrating sand waves. Ocean Dynamics 53(3), 232-238.

Besio G., Blondeaux P., Brocchini M., Hulscher S.J.M.H., Idier D., Knaapen M.A.F. et al. 2008. The morphodynamics of tidal sand waves: a model overview. Coastal Engineering 55(7), 657-670.

Biscara L., Hanquiez V., Leynaud D., Marieu V., Mulder T., Gallissaires J.M. et al. 2012. Submarine slide initiation and evolution offshore Pointe Odden, Gabon-Analysis from annual bathymetric data (2004-2009). Marine Geology 299, 43-50.

Blackford J., Stahl H., Bull J.M., Bergès B.J.P., Cevatoglu M., Lichtschlag A. et al. 2014. Detection and impacts of leakage from sub-seafloor deep geological carbon dioxide storage. Nature Climate Change 4(11), 1011-1016.

Blum J.A., Nooner S.L. and Zumberge M.A. 2008. Recording Earth strain with optical fibers. IEEE Sensors Journal 8(7), 1152-1160.

Blum J.A., Chadwell C.D., Driscoll N. and Zumberge M.A. 2010. Assessing slope stability in the Santa Barbara Basin, California, using seafloor geodesy and CHIRP seismic data. Geophysical Research Letters 37(13).

Bruschi R., Bughi S., Spinazzè M., Torselletti E. and Vitali L. 2006. Impact of debris flows and turbidity currents on seafloor structures. Norsk Geologisk Tidsskrift 86(3), 317.

Bornhold B.D., Ren P. and Prior D.B. 1994. High-frequency turbidity currents in British Columbia fjords. Geo-Marine Letters 14(4), 238-243.

Burtin A., Cattin R., Bollinger L., Vergne J., Steer P., Robert A. et al. 2011. Towards the hydrologic and bed load monitoring from highfrequency seismic noise in a braided river: The "torrent de St Pierre", French Alps. Journal of Hydrology 408(1), 43-53.

Campbell K.J. 1999. Deepwater geohazards: how significant are they? The Leading Edge 18(4), 514-519.

Campbell K.J., Kinnear S. and Thame A. 2015. AUV technology for seabed characterization and geohazards assessment. The Leading Edge 34(2), 170-178.

Caplan-Auerbach J., Dziak R.P., Bohnenstiehl D.R., Chadwick W.W. and Lau T.K. 2014. Hydroacoustic investigation of submarine landslides at West Mata volcano, Lau Basin. Geophysical Research Letters 41(16), 5927-5934.

Carter L., Burnett D., Drew S., Hagadorn L., Marle G., Bartlett-McNeil D. et al. 2009. Submarine cables and the oceans-Connecting the world. UNEP-WCMC Biodiversity Series 31. ICPC/UNEP/UNEPWCMC (64pp.).

Carter L., Gavey R., Talling P. and Liu J. 2014. Insights into submarine geohazards from breaks in subsea telecommunication cables. Oceanography 27(2), 58-67.

Carter L., Milliman J.D., Talling P.J., Gavey R. and Wynn R.B. 2012. Near-synchronous and delayed initiation of long run-out submarine sediment flows from a record-breaking river flood, offshore Taiwan. Geophysical Research Letters 39(12).

Chillarige A.V., Morgenstern N.R., Robertson P.K. and Christian H.A. 1997. Seabed instability due to flow liquefaction in the Fraser River delta. Canadian Geotechnical Journal 34(4), 520-533.

Clare M.A., Thomas S., Mansour M. and Cartigny M.E. 2015a. Turbidity current hazard assessment for field layout planning. Proceedings of the Third International Symposium on Frontiers in Offshore Geotechnics, Perth, Australia, June 2015.

Clare M.A., Cartigny M.J.B., North L.J., Talling P.J., Vardy M.E., Hizzett J.L. et al. 2015b. Quantification of near-bed dense layers and implica- 
tions for seafloor structures: new insights into the most hazardous aspects of turbidity currents. Proceedings of the Offshore Technology Conference.

Clare M.A., Hughes Clarke J.E., Talling P.J., Cartigny M.J.B. and Pratomo D.G. 2016. Preconditioning and triggering of offshore slope failures and turbidity currents revealed by most detailed monitoring yet at a fjordhead delta. Earth and Planetary Science Letters 450, 208-220.

Conway K.W., Barrie J.V., Picard K. and Bornhold B.D. 2012. Submarine channel evolution: active channels in fjords, British Columbia, Canada. Geo-Marine Letters 32(4), 301-312.

Cooper C., Wood J. and Andrieux O. 2013. Turbidity current measurements in the Congo Canyon. Proceedings of Offshore Technology Conference, Houston, TX, May 1-4, 2013.

Corbett D.R., Walsh J.P., Harris C.K., Ogston A.S. and Orpin A.R. 2014. Formation and preservation of sedimentary strata from coastal events: insights from measurements and modeling. Continental Shelf Research 86, $1-5$.

Dai Z.Y., Liu Y., Zhang L.X., Ou Z.H., Zhou C. and Liu Y.Z. 2008. Landslide monitoring based on high-resolution distributed fiber optic stress sensor. Optical Fiber Sensors Conference. APOS'08. 1st AsiaPacific, pp. 1-4).

Dan G., Sultan N. and Savoye B. 2007. The 1979 Nice harbour catastrophe revisited: trigger mechanism inferred from geotechnical measurements and numerical modelling. Marine Geology 245(1), 40-64.

Delaney J.R. and Kelley D.S. 2015. Next-generation science in the ocean basins: expanding the oceanographer's toolbox utilizing submarine electro-optical sensor networks. In: Seafloor Observatories, pp. 465502. Springer Berlin Heidelberg.

Emeana C.J., Hughes T.J., Dix J.K., Gernon T.M., Henstock T.J., Thompson C.E.L. et al. 2016. The thermal regime around buried submarine high voltage cables. Geophysical Journal International.

Evans T.G. 2010. A systematic approach to offshore engineering for multiple-project developments in geohazardous areas. In: Frontiers in Offshore Geotechnics II, pp. 3-32. London, UK: CRC Press.

Favali P. and Beranzoli L. 2006. Seafloor observatory science: a review. Annals of Geophysics 49(2-3).

Favali P., Beranzoli L. and De Santis A. 2015. Seafloor observatories: a new vision of the Earth from the abyss. Springer Science and Business Media.

Forsberg C.F., Heyerdahl H. and Solheim A. 2016. Underwater mass movements in lake Mjøsa, Norway. In: Submarine Mass Movements and Their Consequences, pp. 191-199. Springer International Publishing.

Fox C.G., Chadwick W.W. and Embley R.W. 1992. Detection of changes in ridge-crest morphology using repeated multibeam sonar surveys. Journal of Geophysical Research: Solid Earth 97(B7), 11149-11162.

Gafeira J., Long D. and Diaz-Doce D. 2012. Semi-automated characterisation of seabed pockmarks in the central North Sea. Near Surface Geophysics 10(4), 303-314.

Gartner J.W. 2004. Estimating suspended solids concentrations from backscatter intensity measured by acoustic Doppler current profiler in San Francisco Bay, California. Marine Geology 211(3), 169-187.

Gavey R., Carter L., Liu J.T., Talling P.J., Hsu R., Pope E. et al. 2016. Frequent sediment density flows during 2006 to 2015, triggered by competing seismic and weather events: observations from subsea cable breaks off southern Taiwan. Marine Geology.

Gray T., Dingler J. and Wood G. 2013. Multiscale seabed seepage manifestations in the South Caspian Basin, Azerbaijan. Offshore Technology Conference.

Griffiths G. and Flatt D. 1987. A self-contained acoustic Doppler current profiler-design and operation. Fifth International Conference on Electronics for Ocean Technology, Heriot-Watt University, Edinburgh, pp. 41-47.
Gutowski G., Bull, J.M., Dix J., Henstock T., Hogarth P., White P. et al. 2002. Chirp sub-bottom profiler source signature design and field testing. Marine Geophysical Researches 23, 481-492.

Haflidason H., Lien R., Sejrup H.P., Forsberg C.F. and Bryn P. 2005. The dating and morphometry of the Storegga Slide. Marine and Petroleum Geology 22(1), 123-136.

Hage S., Cartigny M., Clare M., Talling P., Sumner E., Vardy M. et al. 2016. A multi-instrument approach to monitoring turbidity currents: case study from the Squamish Delta, British Columbia (Canada). In: EGU General Assembly Conference Abstracts, Vol. 18, p. 13038.

Harris J., Whitehouse R., Todd D., Gunn I. and Lewis R. 2016. Analysing scour interaction between submarine pipelines, valve stations and mechanical protection structures. Proceedings Offshore Technology Conference, Houston, TX, May 2-5, 2016. Paper OTC-27289-MS.

Hart J.K. and Martinez K. 2006. Environmental sensor networks: a revolution in the earth system science? Earth-Science Reviews 78(3), 177-191.

Hauswirth D., Puzrin A.M., Carrera A., Standing J.R. and Wan M.S.P. 2014. Use of fibre-optic sensors for simple assessment of ground surface displacements during tunnelling. Geotechnique 64(10), 837842.

Heeschen K.U., Tréhu A.M., Collier R.W., Suess E. and Rehder G. 2003. Distribution and height of methane bubble plumes on the Cascadia Margin characterized by acoustic imaging. Geophysical Research Letters 30(12).

Heezen B.C. and Ewing M. 1952. Turbidity currents and submarine slumps, and the 1929 Grand Banks earthquake. American Journal of Science 250(12), 849-873.

Hickin E.J. 1989. Contemporary Squamish River sediment flux to Howe Sound, British Columbia. Canadian Journal of Earth Sciences 26(10), 1953-1963.

Hill A.J., Southgate J.G., Fish P.R. and Thomas S. 2011. Deepwater Angola part I: Geohazard mitigation. Frontiers in Offshore Geotechnics II, 209-214.

Hiscott R.N., Aksu A.E., Flood R.D., Kostylev V. and Yaşar D. 2013. Widespread overspill from a saline density-current channel and its interaction with topography on the south-west Black Sea shelf. Sedimentology 60(7), 1639-1667.

Holdaway G.P., Thorne P.D., Flatt D., Jones S.E. and Prandle D. 1999. Comparison between ADCP and transmissometer measurements of suspended sediment concentration. Continental Shelf Research 19(3), 421-441.

Hovland M., Gardner J.V. and Judd A.G. 2002. The significance of pockmarks to understanding fluid flow processes and geohazards. Geofluids 2(2), 127-136.

Hughes Clarke J.E. 2016. First wide-angle view of channelized turbidity currents links migrating cyclic steps to flow characteristics. Nature Communications 7, 11896.

Hughes Clarke J.E. 2012. Optimal use of multibeam technology in the study of shelf morphodynamics. In: Sediments, Morphology and Sedimentary Processes on Continental Shelves: Advances in Technologies, Research and Applications. International Association of Sedimentologists Special Publication 44, 3-28.

Hughes Clarke J.E., Brucker S., Muggah J., Hamilton T., Cartwright D., Church I. et al. 2012. Temporal progression and spatial extent of mass wasting events on the Squamish prodelta slope. In: Landslides and Engineered Slopes: Protecting Society Through Improved Understanding, 1091-1096.

Hughes Clarke J.E., Marques C.R.V. and Pratomo D. 2014. Imaging active mass-wasting and sediment flows on a fjord delta, Squamish, British Columbia. In: Submarine Mass Movements and Their Consequences, pp. 249-260. Springer International Publishing. 
Inaudi D. and Glisic B. 2007. The 3rd International Conference on Structural Health Monitoring of Intelligent Infrastructure, Vancouver, Canada, November 13-16, 2007.

Inman D.L., Nordstrom C.E. and Flick R.E. 1976. Currents in submarine canyons: an air-sea-land interaction. Annual Review of Fluid Mechanics 8(1), 275-310.

Jones D.O., Walls A., Clare M., Fiske M.S., Weiland R.J., O'Brien R. et al. 2014. Asphalt mounds and associated biota on the Angolan margin. Deep Sea Research Part I: Oceanographic Research Papers 94, 124-136.

Kaiser M.J., Yu Y. and Jablonowski C.J. 2009. Modeling lost production from destroyed platforms in the 2004-2005 Gulf of Mexico hurricane seasons. Energy 34(9), 1156-1171.

Kelner M., Migeon S., Tric E., Couboulex F., Dano A., Lebourg T. et al. 2016. Frequency and triggering of small-scale submarine landslides on decadal timescales: analysis of 4D bathymetric data from the continental slope offshore Nice (France). Marine Geology 379, 281-297.

Kelley D.S., Delaney J.R. and Juniper S.K. 2014. Establishing a new era of submarine volcanic observatories: cabling axial seamount and the endeavour segment of the Juan de Fuca Ridge. Marine Geology 352, 426-450.

Khripounoff A., Vangriesheim A., Babonneau N., Crassous P., Dennielou B. and Savoye B. 2003. Direct observation of intense turbidity current activity in the Zaire submarine valley at $4000 \mathrm{~m}$ water depth. Marine Geology 194(3), 151-158.

Kostaschuk R., Best J., Villard P., Peakall J. and Franklin M. 2005. Measuring flow velocity and sediment transport with an acoustic Doppler current profiler. Geomorphology 68(1), 25-37.

Kvalstad T.J., Nadim F., Kaynia A.M., Mokkelbost K.H. and Bryn P. 2005. Soil conditions and slope stability in the Ormen Lange area. Marine and Petroleum Geology 22(1), 299-310.

LaBonte A.L., Brown K.M. and Tryon M.D. 2007. Monitoring periodic and episodic flow events at Monterey Bay seeps using a new optical flow meter. Journal of Geophysical Research: Solid Earth 112(B2).

Lane S.N., Richards K.S. and Chandler J.H. 1994. Developments in monitoring and modelling small-scale river bed topography. Earth Surface Processes and Landforms 19(4), 349-368.

Lin C.H., Kumagai H., Ando M. and Shin T.C. 2010. Detection of landslides and submarine slumps using broadband seismic networks. Geophysical Research Letters 37(22).

Lintern D.G. and Hill P.R. 2010. An underwater laboratory at the Fraser River delta. Eos, Transactions American Geophysical Union 91(38), 333-334.

Lintern D.G., Hill P.R. and Stacey C. 2016. Powerful unconfined turbidity current captured by cabled observatory on the Fraser River delta slope, British Columbia, Canada. Sedimentology.

Martinez K., Hart J.K. and Ong R. 2004. Environmental sensor networks. Computer 37(8), 50-56.

Masoudi A., Belal M. and Newson T.P. 2013. A distributed optical fibre dynamic strain sensor based on phase-OTDR. Measurement Science and Technology, 24(8), 085204.

Mastbergen D., van den Ham G., Cartigny M., Koelewijn A., de Kleine M., Clare M. et al. 2016. Multiple flow slide experiment in the Westerschelde Estuary, The Netherlands. In: Submarine Mass Movements and Their Consequences, pp. 241-249. Springer International Publishing.

McHugh C.M., Kanamatsu T., Seeber L., Bopp R., Cormier M.H. and Usami K. 2016. Remobilization of surficial slope sediment triggered by the AD $2011 \mathrm{Mw} 9$ Tohoku-Oki earthquake and tsunami along the Japan Trench. Geology 44(5), 391-394.

Moernaut J., Van Daele M., Strasser M., Clare M.A., Heirman K., Viel M. et al. 2015. Lacustrine turbidites produced by surficial slope sediment remobilization: a mechanism for continuous and sensitive turbidite paleoseismic records. Marine Geology.
Mosher D.C., Moscardelli L., Shipp R.C., Chaytor J.D., Baxter C.D., Lee H.J. et al. 2010. Submarine Mass Movements and Their Consequences, pp. 1-8. Springer Netherlands.

Moss J.L., Cartwright J., Cartwright A. and Moore R. 2012. The spatial pattern and drainage cell characteristics of a pockmark field, Nile Deep Sea Fan. Marine and Petroleum Geology 35(1), 321-336.

Nimblett J.N., Shipp R.C. and Strijbos F. 2005. Gas hydrate as a drilling hazard: examples from global deepwater settings. Offshore Technology Conference.

Parker E.J., Traverso C., Del Giudice T., Evans T. and Moore R. 2009. Geohazard risk assessment-vulnerability of subsea structures to geohazards-risk implications. Offshore Technology Conference.

Paull C.K., Ussler III W., Caress D.W., Lundsten E., Covault J.A., Maier K.L. et al. 2010a. Origins of large crescent-shaped bedforms within the axial channel of Monterey Canyon, offshore California. Geosphere 6(6), 755-774.

Piper D.J., Cochonat P. and Morrison M.L. 1999. The sequence of events around the epicentre of the 1929 Grand Banks earthquake: initiation of debris flows and turbidity current inferred from sidescan sonar. Sedimentology 46(1), 79-97.

Pope E.L., Talling P.J. and Carter L. 2016. Which earthquakes trigger damaging submarine mass movements: insights from a global record of submarine cable breaks? Marine Geology.

Pope E., Talling P.J., Carter L., Clare M.A. and Hunt J.E. 2017. Damaging sediment density flows triggered by tropical cyclones. Earth and Planetary Science Letters.

Prior D.B. and Suhayda J.N. 1979. Application of infinite slope analysis to subaqueous sediment instability, Mississippi Delta. Engineering Geology 14(1), 1-10.

Prior D.B., Bornhold B.D., Wiseman Jr W.J. and Lowe D.R. 1987. Turbidity current activity in a British Columbia fjord. Science 237, 1330-1334.

Reichel G. and Nachtnebel H.P. 1994. Suspended sediment monitoring in a fluvial environment: advantages and limitations applying an acoustic Doppler current profiler. Water Research 28(4), 751-761.

Rennie C.D., Millar R.G. and Church M.A. 2002. Measurement of bed load velocity using an acoustic Doppler current profiler. Journal of Hydraulic Engineering 128(5), 473-483.

Richards A.F., Øten K., Keller G.H. and Lai J.Y. 1975. Differential piezometer probe for an in situ measurement of sea-floor. Geotechnique 25(2), 229-238.

RDI Instruments. 2015. Glossary, accessed from RDI Instruments website: Accessed 28 January 2015 [Available at http://www.rdinstruments.com/glossary.aspx].

Schlaberg H.I., Baas J.H., Wang M., Best J.L., Williams R.A. and Peakall J. 2006. Electrical resistance tomography for suspended sediment measurements in open channel flows using a novel sensor design. Particle and Particle Systems Characterization 23(3)-(4), 313-320.

Schimel A.C., Ierodiaconou D., Hulands L. and Kennedy D.M. 2015. Accounting for uncertainty in volumes of seabed change measured with repeat multibeam sonar surveys. Continental Shelf Research 111, $52-68$.

Schock G. and LeBlanc L.R. 1990. Chirp xonar: new technology for subbottom profiling. Sea Technology 31(9), 35-43.

Selker J.S., Thevenaz L., Hwald H., Mallet A., Luxemburg W., van de Giesen N. et al. 2006. Distributed fiber-optic temperature sensing for hydrologic systems. Water Resources Research 42, W12202.

Sgroi T., Monna S., Embriaco D., Giovanetti G., Marinaro G. and Favali P. 2014. Geohazards in the Western Ionian Sea. Oceanography 27(2), 154.

Skogdalen J.E. and Vinnem J.E. 2012. Quantitative risk analysis of oil and gas drilling, using Deepwater Horizon as case study. Reliability Engineering and System Safety 100, 58-66. 
Skvortsov A. and Bornhold B. 2007. Numerical simulation of the landslide-generated tsunami in Kitimat Arm, British Columbia, Canada, 27 April 1975. Journal of Geophysical Research: Earth Surface 112(F2).

Sleath J.F.A. 1991. Velocities and concentrations in oscillatory flow over beds of sediment. Journal of Fluid Mechanics 233, 165-196.

Smith D.P., Kvitek R., Iampietro P.J. and Wong K. 2007. Twenty-nine months of geomorphic change in upper Monterey Canyon (20022005). Marine Geology 236(1), 79-94.

Soubaras R. and Dowle R. 2010. Variable-depth streamer-A broadband marine solution. First Break 28(12).

Spinewine B., Rensonnet D., Clare M., Capart H., De Thier T. and Danunterseh G. 2013. Numerical modelling of runout and velocity for slide-induced submarine density flows: a building block of an integrated geohazards assessment for deepwater developments. Offshore Technology Conference.

Stegmann S., Sultan N., Kopf A., Apprioual R. and Pelleau P. 2011. Hydrogeology and its effect on slope stability along the coastal aquifer of Nice, France. Marine Geology 280(1), 168-181.

Strout J.M. and Tjelta T.I. 2005. In situ pore pressures: what is their significance and how can they be reliably measured? Marine and Petroleum Geology 22(1), 275-285.

Sullivan C. 2015. Researchers track underwater avalanches like never before. $\operatorname{Eos} 96$

Sultan N., Cochonat P., Canals M., Cattaneo A., Dennielou B., Haflidason H. et al. 2004. Triggering mechanisms of slope instability processes and sediment failures on continental margins: a geotechnical approach. Marine Geology 213(1), 291-321.

Sumner, E.J. and Paull C.K. 2014. Swept away by a turbidity current in Mendocino submarine canyon, California. Geophysical Research Letters 41(21), 7611-7618.

Syahnur Y. and Jaya K.A. 2016. Geomatics best practices in Saka Indonesia Pangkah Limited (Case Study: Ujung Pangkah Pipeline Integrity). 2015 Indonesian Petroleum Association Convention.

Symons W.O., Sumner E.J., Paull C.K., Cartigny M.J.B., Xu J.P., Maier K.L. et al. 2017. A new model for turbidity current behavior based on integration of flow monitoring and precision coring in a submarine canyon. Geology 45(4), 367-370.

Talling P.J., Wynn R.B., Masson D.G., Frenz M., Cronin B.T., Schiebel R. et al. 2007. Onset of submarine debris flow deposition far from original giant landslide. Nature 450(7169), 541-544.

Talling P.J., Paull C.K. and Piper D.J. 2013. How are subaqueous sediment density flows triggered, what is their internal structure and how does it evolve? Direct observations from monitoring of active flows. Earth-Science Reviews 125, 244-287.

Talling P., Clare M., Urlaub M., Pope E., Hunt J. and Watt S. 2014. Large submarine landslides on continental slopes: geohazards, methane release, and climate change. Oceanography 27(2), 32-45.

Talling P.J., Allin J., Armitage D.A., Arnott R.W.C., Cartigny M.J.B., Clare M.A. et al. 2015. Key future directions for research on turbidity currents and their deposits. Journal of Sedimentary Research 85(2), 153-169.

Thomas S., Hooper J. and Clare M. 2010. Constraining geohazards to the past: impact assessment of submarine mass movements on seabed developments. In: Submarine Mass Movements and Their Consequences, pp. 387-398. Springer Netherlands.

Thomas S., Hill A.J., Clare M.A., Shreeve J.W. and Unterseh S. 2011. Understanding engineering challenges posed by natural hydrocarbon infiltration and the development of Authigenic Carbonate. Offshore Technology Conference.

Thorne P.D., Hardcastle P.J. and Soulsby R.L. 1993. Analysis of acoustic measurements of suspended sediments. Journal of Geophysical Research: Oceans 98(C1), 899-910.
Tom J., Draper S., White D. and O'Neill M. 2016. Risk-based assessment of scour around subsea infrastructure. Proceedings of the Offshore Technology Conference.

Van Lancker V. and Baeye M. 2015. Wave glider monitoring of sediment transport and dredge plumes in a shallow marine sandbank environment. PLOS ONE 10(6), e0128948.

Vanneste M., Sultan N., Garziglia S., Forsberg C.F. and L'Heureux J.S. 2014. Seafloor instabilities and sediment deformation processes: the need for integrated, multi-disciplinary investigations. Marine Geology 352, 183-214.

Vardy M.E. 2015. Deriving shallow-water sediment properties using post-stack acoustic impedance inversion. Near Surface Geophysics 13(2), 143-154.

Vardy M.E., Dix J.K., Henstock T.J., Bull J.M. and Gutowski M. 2008. Decimeter-resolution 3D seismic volume in shallow water: a case study in small-object detection. Geophysics 73(2), B33-B40.

Vardy M.E., L'Heureux J.S., Vanneste M., Longva O., Steiner A., Forsberg C.F. et al. 2012. Multidisciplinary investigation of a shallow near-shore landslide, Finneidfjord, Norway. Near Surface Geophysics 10(4), 267-277.

Vardy M.E., Vanneste M., Henstock T.J., Clare M.A., Forsberg F. and Provenzano G. 2017. State of the art remote characterisation of shallow marine sediments: the road to a fully integrated solution. Near Surface Geophysics.

Veloso M., Grienert J., Mienertm J. and De Batist M. 2015. A new methodology for quantifying bubble flow rates in deep water using splitbeam echosounders: examples from the Arctic offshore NW-Svalbard. Limnology and Oceanography: Methods 13 (2015), 267-287.

Von Deimling J.S., Brockhoff J. and Greinert J. 2007. Flare imaging with multibeam systems: Data processing for bubble detection at seeps. Geochemistry, Geophysics and Geosystems 8(6).

Wheaton J.M., Brasington J., Darby S.E. and Sear D.A. 2010. Accounting for uncertainty in DEMs from repeat topographic surveys: improved sediment budgets. Earth Surface Processes and Landforms 35(2), 136-156.

Whitehouse R.J., Harris J.M., Sutherland J. and Rees J. 2011. The nature of scour development and scour protection at offshore windfarm foundations. Marine Pollution Bulletin 62(1), 73-88.

Williams J., Jaquet J., Thomas R., Syers J., Shukla S., Harris R. et al. 1988. Records of riverborne turbidity currents and indications of slope failures in the Rhone delta of Lake Geneva. Journal of Fisheries and Aquatic Science 41, 1609-1617.

Wilson T.C., Lwiza K.M.M. and Allen G.L. 1997. Oceans 97. MTS/IEEE Conference Proceedings, Halifax, Canada, October 6-9, 1997, 120-125.

Wynn R.B., Huvenne V.A., Le Bas T.P., Murton B.J., Connelly D.P., Bett B.J. et al. 2014. Autonomous underwater vehicles (AUVs): Their past, present and future contributions to the advancement of marine geoscience. Marine Geology 352, 451-468.

Xu J.P., Noble M.A. and Rosenfeld L.K. 2004. In-situ measurements of velocity structure within turbidity currents. Geophysical Research Letters 31(9).

Xu J.P. 2010. Normalized velocity profiles of field-measured turbidity currents. Geology 38(6), 563-566.

Xu J. 2011. Measuring currents in submarine canyons: technological and scientific progress in the past 30 years. Geosphere 7, 868-876.

Xu J.P., Barry J.P. and Paull C.K. 2013. Small-scale turbidity currents in a big submarine canyon. Geology 41(2), 143-146.

Xu J.P., Sequeiros O.E. and Noble M.A. 2014. Sediment concentrations, flow conditions, and downstream evolution of two turbidity currents, Monterey Canyon, USA. Deep Sea Research Part I: Oceanographic Research Papers 89, 11-34. 